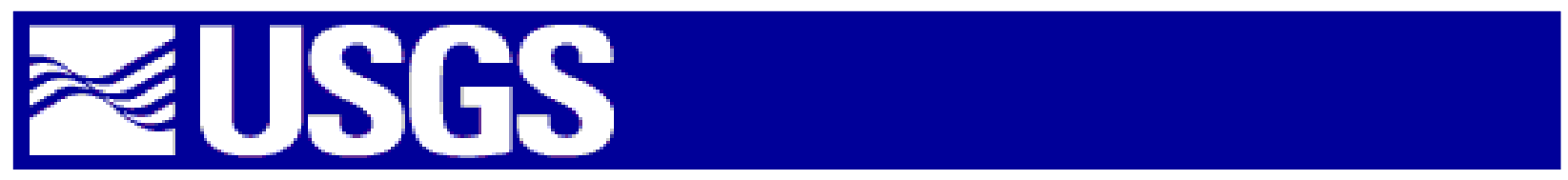

U.S. DEPARTMENT OF THE INTERIOR

U.S. GEOLOGICAL SURVEY

A product of the Place-Based Studies Program, Recoverability and Vulnerability of Desert Ecosystems:

\title{
Recovery of Perennial Vegetation in Military Target Sites in the Eastern Mojave Desert, Arizona
}

By John W. Steiger and Robert H. Webb

Open-File Report OF 00-355

This report is preliminary and has not been reviewed for conformity with the U.S. Geological Survey (USGS) editorial standards or with the North American Stratigraphic Code. Any use of trade, product, or firm names is for descriptive purposes only and does not imply endorsement by the U.S. Government. 


\section{CONTENTS}

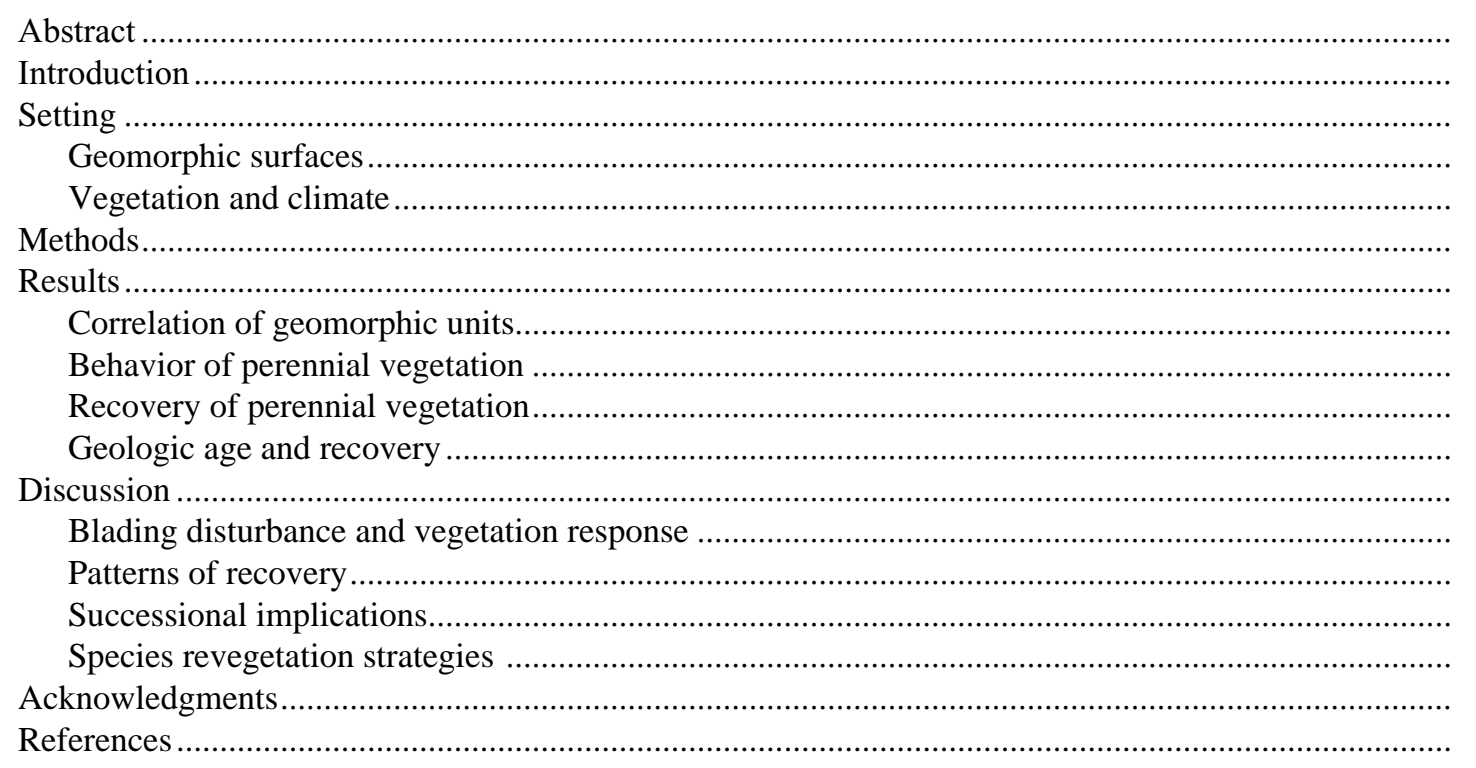

\section{FIGURES}

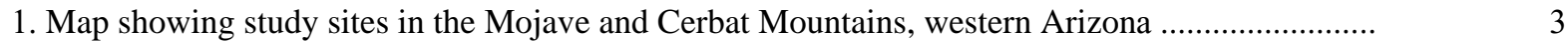

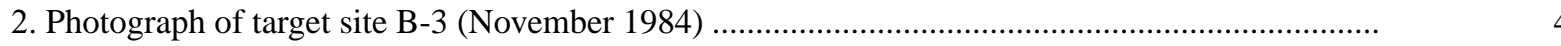

3. Graph showing degree of recovery versus relative geomorphic age for sites in the Mohave Cerbat Mountains

4. Principal-components analysis diagram for sites in the Mojave Mountains and Dutch Henry Flats

\section{TABLES}

1. Surface designations and criteria developed for Quaternary surfaces in the lower Colorado River region).

2. Graph showing degree of recovery versus relative geomorphic age for sites in the Mohave Cerbat Mountains

3. Cover, density, and volume of important perennial species in study sites in the Mohave Mountains and Dutch Henry Flats

4. Cover, density, and volume of important perennial species in study sites in the Cerbat Mountains

5 . Behavior of minor perennial species as indicated by statistically significant $(\mathrm{p}>0.95)$ differences of cover and(or) density in and out of target sites

6. Partial list of the possible effects of blading on selected edaphic characteristics

\section{APPENDICES}

1. Soil descriptions 


\title{
Recovery of Perennial Vegetation in Military Target Sites in the Eastern Mojave Desert, Arizona
}

\author{
By John W. Steiger and Robert H. Webb
}

\begin{abstract}
The effect of the age of geomorphic surfaces on the recovery of desert vegetation in military target sites was studied in the Mohave and Cerbat Mountains of northwestern Arizona. The target sites were cleared of all vegetation during military exercises in 1942-1943 and have not been subsequently disturbed. The degree of recovery was measured by calculating percentagesimilarity (PS) and correlation-coefficient indices on the basis of differences in cover, density, and volume of species growing in and out of each target site. PS values, ranging from 22.7 to 95.1 percent $(100$ percent $=$ identical composition), indicate a wide range of recovery that is partially controlled by the edaphic properties of the geomorphic surfaces. Statistical analyses show a strong pattern that indicates a greater variability in the degree of recovery for sites on older surfaces than on younger surfaces and a weak pattern that indicates an inverse relation between the degree of recovery and geomorphic age. Comparisons of the different effects of target site construction on the edaphic characteristics of each target site provides an explanation for these patterns and suggests the soil properties critical to the recovery process. Statistically significant negative or positive response to disturbance for most species are independent of the age of the geomorphic surfaces; however, there is strong evidence for a shift in response for the common perennial species Acamptopappus sphaerocephalus, and to a lesser extent, Salazaria mexicana, Encelia farinosa, and Coldenia canescens, among different geomorphic surfaces.
\end{abstract}

\section{INTRODUCTION}

The effect of disturbance of geomorphic surfaces of different age on the recovery of desert vegetation is potentially an important issue for land-use managers. Several studies of the natural revegetation of disturbed sites have cited the type of geomorphic surface as a significant factor determining the course of recovery, but past work has focused on the intensity of disturbance or the predisturbance vegetation composition as the primary factors affecting their results. These include studies of excavation pits (Vasek, 1980), utility corridors (Vasek and others, 1975a and b); Kay and Graves, 1980), abandoned agricultural fields (Karpiscak, 1980), nuclear test sites (Romney and others, 1971), abandoned mine sites (Sulenski, 1972), military maneuver areas (Lathrop, 1983;
Prose, 1985; Prose and Metzger, 1985; Prose and others, 1987; Prose and Wilshire, 2000), and abandoned mining towns (Wells, 1961; Webb and Wilshire, 1979; Webb and Newman, 1982; Webb and others, 1983, 1986, 1987, 1988). Some of this work was recently summarized in Lovich and Bainbridge (1999).

Other revegetation studies in arid regions have focused on the effect of the type of geomorphic surface on species composition of communities, but the research has been oriented toward the application of succession theory to deserts. Revegetation sequences, ranging from simple reestablishment of the original species (Mueller, 1940) to seral changes suggestive of classical succession (Vasek and Lund, 1980), have been inferred by studying contemporaneous geomorphic surfaces that represent different stages of landform development. 
The application of succession theory to deserts through the study of spatial patterns of vegetation and geomorphic surfaces has resulted in much controversy, primarily from the shortcomings of the theory itself (Drury and Nisbet, 1973; McIntosh, 1980) or its apparent ill-fit to arid lands (Shreve, 1942; Beatley, 1976; Lathrop and Rowlands, 1983). Nonetheless, strong relations are present between Mojave Desert plant assemblages and the age of geomorphic surfaces (Webb and others, 1987, 1988), as well as in the Sonoran Desert (McAuliffe, 1991, 1994).

Landscapes are a mosaic of geomorphic surfaces of different ages and physical properties. The ages of surfaces may greatly differ although each surface may be composed of similar parent material. Geomorphic surfaces are created or destroyed according to the landscape's disturbance regime (White, 1979) and often will have different soil characteristics according to age (Hunt, 1972). Each set of soil characteristics comprising a geomorphic surface (e.g. surficial morphology, soil texture) may have a different effect on the mantling vegetation.

Depending on the life-history strategies (Grime, 1979) of the resident species, different sets of soil characteristics may not cause differences in species composition across adjacent geomorphic units of different age. Human-caused disturbance, such as bulldozing or grading, may have different effects on the geomorphic surfaces that comprise the landscape and these effects may enhance or diminish the ability of a species to colonize and reproduce.

For example, the removal of the top $100 \mathrm{~mm}$ of a well-developed soil may have more effect on a potential colonizer than the removal of the top 100 $\mathrm{mm}$ of a less-developed soil, even though the species could easily persist once it became established on either type of soil. The course of revegetation, therefore, may be different for two different geomorphic surfaces even though the sites may bear statistically similar compositions of predisturbance vegetation and undergo similar disturbances.

In a study of revegetation resulting from mancaused denudation on a variety of related geomorphic surfaces, Webb and others (1988) found evidence suggestive of an inverse relation between the rate of revegetation and the degree of soil development. In addition, they found that the species composition of disturbed sites converged with increasing time after disturbance to the species composition of assemblages found on the oldest surfaces. Relatively long-lived, maintenanceoriented species dominated the oldest surfaces, whereas short-lived, reproduction-oriented species dominated the recently disturbed surfaces. The data from Webb and others $(1987,1988)$ indicates that the age of geomorphic surfaces has an effect on recovery from disturbance, and life-history strategies of the species involved are important to the sequence of recovery.

Military target sites cleared of vegetation in 1942-1943 provides a basis for a study of the influence of geomorphic surface on revegetation. Identifiable geomorphic surfaces on bajadas extending from the Mohave and Cerbat Mountains of Arizona (fig. 1) can be compared according to relative geomorphic age and differences in edaphic characteristics.

Differences in the degree of recovery of vegetation in target sites constructed on a variety of these units provide an assessment of the relation between increasing age of surfaces and recovery of vegetation on disturbed sites.

\section{SETTING}

At unknown dates between 1942 and 1944, the United States 1st Army, commanded by General George C. Patton, Jr., cleared target sites for military aircraft in the Mojave Desert (Bischoff, 2000). A series of rectangular target sites averaging 4 ha in area were cleared in western Arizona during this time (figs. 1 and 2). The target sites are located on a variety of geomorphic surfaces located in the Mohave Mountains, on Dutch Henry Flats, and on the eastern slopes of the Cerbat Mountains. No information is available on construction and use of these areas; however, aerial photographs taken in 1943 show completely cleared sites, and remnant patterns of the berms indicate the sites were cleared by as few as a single pass of a bulldozer. Field inspection suggested that up to $0.2 \mathrm{~m}$ of surface material was displaced by blading. The sites were primarily used for strafing runs and impact explosives were not used.

The 22 target sites are arranged in three parallel lines of five to eight sites in the Mohave Mountains 


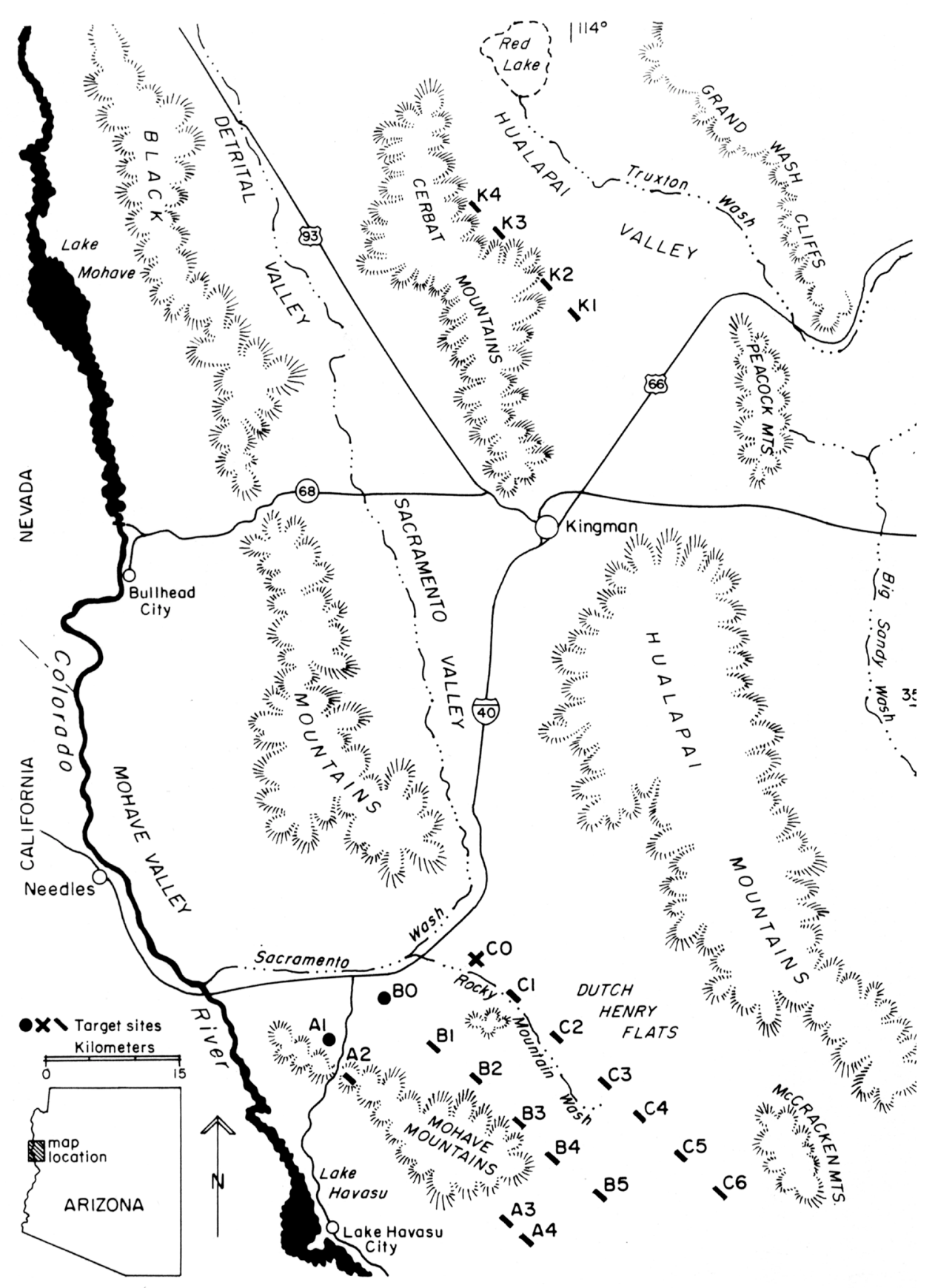

Figure 1. Map of the region including the Mojave and Cerbat Mountains, showing the locations of target sites discussed in this study.

and Dutch Henry Flats area and a line of four sites in the Cerbat Mountains area (fig. 1). The sites are separated by 3 to $5 \mathrm{~km}$ in each line, with the three lines separated by 8 to $10 \mathrm{~km}$ in the Mohave Mountains and Dutch Henry Flats area. Most of the target sites are accessible by dirt road but are isolated and have not been disturbed by land-use practices other than infrequent grazing by range cattle.

\section{Geomorphic Surfaces}

The target sites in the Mohave Mountains were constructed on discrete geomorphic surfaces characterized by alluvial veneers of Quaternary age up to several meters thick on platforms eroded into bedrock. The source rock for these surfaces are Precambrian metamorphic rocks, Miocene volcaniclastic rocks, and Plio-Pleistocene fanglomerates 


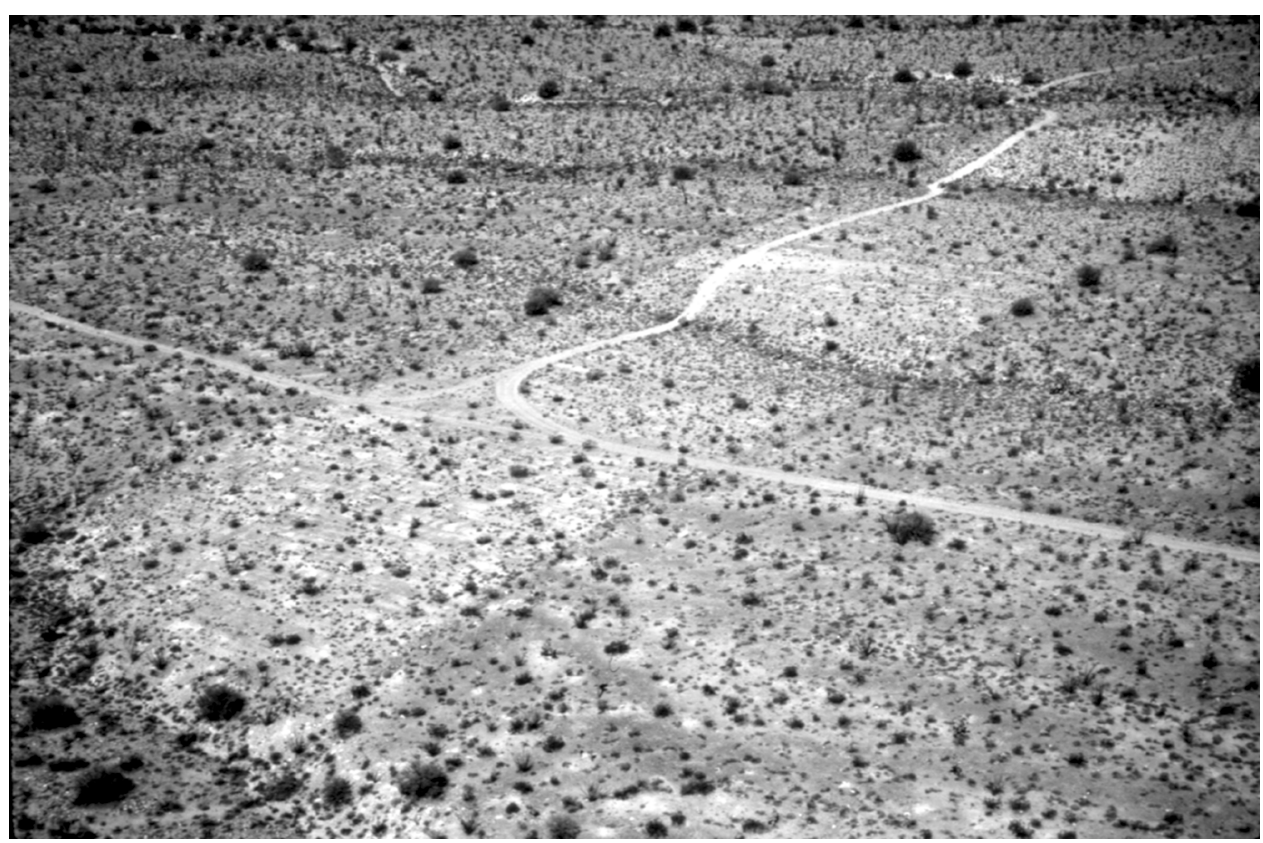

Figure 2. Oblique aerial photograph of target site B-3 (November 1984). The width of the disturbance is $30-40 \mathrm{~m}$. The small trees present are Cercidium microphyllum (Howard G. Wilshire, U.S. Geological Survey).

(Howard and others, 1990, 2000). Wilshire and Reneau (1992) give an overview and discussion of these geomorphic surfaces and provide the geologic basis for our assignment of surface designations.

The target sites in Dutch Henry Flats are on an intermittently active bajada whose source materials are mainly Precambrian metamorphic and igneous rocks eroded from the Hualapai Mountains (fig. 1). The target sites on the eastern slope of the Cerbat Mountains are on a variety of geomorphic surfaces ranging from active flood plains to older alluvial surfaces composed of metamorphic rock detritus.

The geomorphic surfaces in the Mohave Mountains have been classified in a generalized scheme of landform development in response to a series of regional base level falls (Howard and others, in press). The classification system developed by Bull $(1974,1991)$ was used to identify and align the terraces in a sequence of geomorphic units on the basis of relative terrace height, surficial morphology, and degree of pedogenesis (table 1). The oldest units (Q1, PlioPleistocene age) are extensively eroded and are composed of locally-derived alluvium. No remnant of the original geomorphic surface remains for Q1 units, which are characterized by reworked alluvium irregularly overlying relict petrocalcic or argillic horizons. The next oldest units (Q2, Q3a; Pleistocene-Holocene age) are variably eroded surfaces with well-developed desert pavement and a soil with a calcic horizon. Active to recently active units (Q3b, Q4; Holocene age) is characterized by well-developed bar-and-swale topography and weak soil development (table 1). These surfaces are composed of coarse gravels and cobbles near mountain fronts.

Distinctions among the surfaces are sometimes difficult due to the interfingering effect of alluvial deposition and differential erosion rates. However, analyses of soil profiles, surficial morphology, and relation to surrounding units can be used to differentiate surfaces. The geomorphic surfaces on Dutch Henry Flats and in the Cerbat Mountains have not been classified according to the Q-unit system developed by Bull $(1974,1991)$; however, surfaces in these areas can be tentatively correlated with those found in the Mohave Mountains by comparing the relative degree of soil development.

\section{Vegetation and Climate}

The vegetation in and around the target sites is Mojave Desert-Sonoran Desert Transition vegetation with major species from both deserts 
Table 1. Surface designation and criteria developed by Bull (1974) for Quaternary geomorphic surfaces in the Upper Colorado River region, Arizona-California, as applied by Howard and others (1990, 2000) and Wilshire and Reneau (1992) in the Mohave Mountains of western Arizona.

\begin{tabular}{|c|c|c|c|c|c|}
\hline SURFACE & GENERAL DESCRIPTION & POSITION & $\begin{array}{l}\text { SURFICIAL }^{1} \\
\text { MORPHOLOGY }\end{array}$ & SOIL PROFILE & AGE (yrs bp) ${ }^{2}$ \\
\hline Q1 & $\begin{array}{l}\text { Isolated ridges, highly } \\
\text { eroded surfaces. } \\
\text { Moderately well-bedded to } \\
\text { unbedded gravel, sandy } \\
\text { gravel, and gravelly sand. }\end{array}$ & $\begin{array}{l}\text { Highly } \\
\text { variable }\end{array}$ & $\begin{array}{l}\text { Absent to slight pavement } \\
\text { and varnish. Caliche } \\
\text { fragments typically present. } \\
\text { No channelization or gravel } \\
\text { bars. }\end{array}$ & $\begin{array}{l}\text { B horizon usually not } \\
\text { preserved. K horizon } \\
\text { (stage III-IV) highly } \\
\text { eroded, occasionally } \\
\text { exposed. }\end{array}$ & $200,000-1,500,000$ \\
\hline Q2a & $\begin{array}{l}\text { Well1preserved surface } \\
\text { with little to no dissection. } \\
\text { Moderately well to poorly } \\
\text { bedded sandy gravel and } \\
\text { gravelly sand. }\end{array}$ & $\begin{array}{l}1.7 \text { to } 4.5 \mathrm{~m} \\
\text { above active } \\
\text { channel }\end{array}$ & $\begin{array}{l}\text { Moderate to strong pave- } \\
\text { ment and varnish. Subdued } \\
\text { bar/swale topography near } \\
\text { mountain front, smoother } \\
\text { elsewhere. }\end{array}$ & $\begin{array}{l}\mathrm{A}_{\mathrm{V}} \text { and } \mathrm{B} \text { horizons } \\
\text { well-developed. Stage } \\
\text { II-III K horizon. }\end{array}$ & $50,000-200,000$ \\
\hline Q2b & $\begin{array}{l}\text { Similar to Q2a but slightly } \\
\text { more dissected. }\end{array}$ & $\begin{array}{l}1.5 \text { to } 1.75 \mathrm{~m} \\
\text { above active } \\
\text { channel }\end{array}$ & Similar to Q2a. & $\begin{array}{l}\text { Similar to Q2a but K } \\
\text { horizon less developed. }\end{array}$ & $11,000-50,000$ \\
\hline Q3a & $\begin{array}{l}\text { Bar/swale topography with } \\
\text { coarse to extremely coarse } \\
\text { materials overlying finer- } \\
\text { grained materials. }\end{array}$ & $\begin{array}{l}1 \text { to } 4 \mathrm{~m} \\
\text { above active } \\
\text { channel }\end{array}$ & $\begin{array}{l}\text { Slight to moderate pave- } \\
\text { ment and varnish. Gravel } \\
\text { bars easily discernible. }\end{array}$ & $\begin{array}{l}\mathrm{A}_{\mathrm{v}} \text { and } \mathrm{B} \text { horizons ab- } \\
\text { sent or weakly deve- } \\
\text { loped. Weak to moder- } \\
\text { ate stage I K horizon. }\end{array}$ & $2,000-11,000$ \\
\hline Q3b & $\begin{array}{l}\text { Similar to Q3a but coarse } \\
\text { material generally larger. }\end{array}$ & $\begin{array}{l}1 \text { to } 2 \mathrm{~m} \\
\text { above active } \\
\text { channel }\end{array}$ & $\begin{array}{l}\text { Pavement and varnish } \\
\text { absent. Gravel bars well } \\
\text { developed. Channelization } \\
\text { poorly developed. }\end{array}$ & $\begin{array}{l}\text { Weak } A_{v} \text { horizon and } \\
\text { pavement. B horizon } \\
\text { absent. K horizon weak } \\
\text { stage I or non-existent. }\end{array}$ & $0-2,000$ \\
\hline Q4 & $\begin{array}{l}\text { Active or recently active } \\
\text { alluvial channel. }\end{array}$ & $\begin{array}{l}\text { Active } \\
\text { channel }\end{array}$ & $\begin{array}{l}\text { Bar and swale topography } \\
\text { predominates. }\end{array}$ & No soil development. & $0-2,000$ \\
\hline
\end{tabular}

${ }^{1}$ From Wilshire and Reneau (1992).

${ }^{2}$ Ages are estimated by Bull (1974).

present and dominating according to habitat (Brown and Lowe, 1980). Larrea tridentata and Ambrosia dumosa codominate in the Mohave Mountains and Dutch Henry Flats. Fouquieria splendens and Opuntia sp. are important locally in Dutch Henry Flats and Krameria sp. and Encelia virginensis are abundant locally in the Mohave Mountains. Acamptoppapus sphaerocephalus, Hymenoclea, and Salazaria mexicana codominate in the Cerbat Mountains with Acacia greggii and Krameria sp. are important locally.

The Mohave Mountains and Dutch Henry Flats are about 460-700 $\mathrm{m}$ in elevation, have low annual precipitation, and experience high summer temperatures. Between 1967 and 1982, Lake Havasu City (fig. 1) had an average of 112 days/year with temperatures greater than or equal to $37^{\circ} \mathrm{C}$ and a mean annual rainfall of $115 \mathrm{~mm}$. Weather data for the same period from Kingman (fig. 1), the nearest town to the Cerbat Mountain sites indicate an average of 17 days/year with temperatures greater or equal to $37^{\circ} \mathrm{C}$ and $245 \mathrm{~mm}$ mean annual rainfall
(Sellers and others, 1985). The sites in the Cerbat Mountains are at about 1,000-1,100 m elevation.

\section{METHODS}

Six target sites in the Mohave Mountains, two on Dutch Henry Flats, and two on the eastern slope of the Cerbat Mountains were selected for study. The target sites occurred on surfaces representative of the major geomorphic surfaces found within each geographical area. Surficial morphology, major soil-profile characteristics, and corresponding surface designations of selected target sites are given in table 2. Target site K-2 was constructed across two distinct geomorphic units which were measured separately as K-2y and K-2o. Soil profiles were described and compared from trenches usually $1 \mathrm{~m}$ deep and bracketing the transect lines to confirm the continuity of geomorphic units in control and target sites. Classification terminology for calcic horizons follows 
Table 2. Characteristics of geomorphic surfaces and perennial vegetation assemblages for all study sites. Combined PS values are calculated by taking the mean of the cover and density PS values.

\begin{tabular}{|c|c|c|c|c|c|c|c|}
\hline SITE & SURFICIAL MORPHOLOGY & SOIL CHARACTERISTICS ${ }^{1}$ & UNIT & COVER & $\begin{array}{l}\text { PS } \\
\text { VALUES } \\
\text { DENSITY }\end{array}$ & COMBINED & $\begin{array}{c}\text { CC } \\
\text { VALUE }\end{array}$ \\
\hline A-2 & $\begin{array}{l}\text { Well developed bar/swale } \\
\text { topography, primarily } \\
\text { cobbles/pebbles. No } \\
\text { pavement or varnish. } \\
\text { Channels prevalent. }\end{array}$ & $\begin{array}{l}\text { No B horizon, Stage I K } \\
\text { horizon. }\end{array}$ & Q3b & 72.7 & 65.3 & 69.0 & 0.88 \\
\hline A-4 & $\begin{array}{l}\text { Very slight bar/swale } \\
\text { topography. Patches of } \\
\text { varnished pavement. Terrace } \\
2 \mathrm{~m} \text { above active channel. }\end{array}$ & $\begin{array}{l}30-60 \mathrm{~cm} \text { of weakly developed } \\
\text { soil (some interstitial } \\
\text { carbonate) over a well- } \\
\text { developed B horizon or Stage } \\
\text { II-III K horizon. }\end{array}$ & $\begin{array}{l}\text { Q3a over } \\
\text { remnant } \\
\text { Q2 }\end{array}$ & 84.4 & 87.5 & 86.0 & 0.97 \\
\hline B-1 & $\begin{array}{l}\text { Isolated ridgetops. Slight } \\
\text { pavement of pebbles/gravel. } \\
\text { Very slight varnish. }\end{array}$ & $\begin{array}{l}\text { Weak A horizon. No } \\
\text { discernible B horizon. Stage } \\
\text { III K horizon. }\end{array}$ & Q1 & 98.9 & 91.2 & 95.1 & 0.99 \\
\hline B-2 & $\begin{array}{l}\text { Well varnished pavement } \\
\text { occasionally broken by } \\
\text { patches of vegetation. } \\
\text { Ridges. }\end{array}$ & $\begin{array}{l}\text { Strong } \mathrm{A}_{\mathrm{V}} \text { and } \mathrm{B} \text { horizons. } \\
\text { Stage III K horizon. }\end{array}$ & Q2a & 75.2 & 74.6 & 74.9 & 0.92 \\
\hline B-3 & $\begin{array}{l}\text { Ridgetop. No varnish or } \\
\text { pavement. No caliche } \\
\text { fragments on surface. }\end{array}$ & $\begin{array}{l}\text { No discernible B horizon. } \\
\text { Stage IV K horizon. }\end{array}$ & Q1 & 56.0 & 60.3 & 58.1 & 0.62 \\
\hline B-5 & $\begin{array}{l}\text { Slope with surface exposures } \\
\text { of laminar carbonate. Many } \\
\text { caliche fragments. }\end{array}$ & $\begin{array}{l}0-40 \mathrm{~cm} \text { of slightly oxidized } \\
\text { material above Stage IV K } \\
\text { horizon. }\end{array}$ & Q1s & 28.6 & 16.8 & 22.7 & 0.44 \\
\hline \multicolumn{8}{|c|}{ Dutch Henry Flats } \\
\hline $\mathrm{C}-0$ & $\begin{array}{l}\text { Intermittently active bajada. } \\
\text { Mostly fine-grained } \\
\text { materials. }\end{array}$ & $\begin{array}{l}\text { No discernible B horizon. } \\
\text { Weak Stage II K horizon. }\end{array}$ & Q3a ${ }^{2}$ & 75.0 & 82.3 & 78.7 & 0.92 \\
\hline $\mathrm{C}-1$ & Similar to C-0 & $\begin{array}{l}\text { Similar to C-0 but K horizon } \\
\text { better developed. }\end{array}$ & $\mathrm{Q}^{2} \mathrm{a}^{2}$ & 76.4 & 86.1 & 81.3 & 0.93 \\
\hline \multicolumn{8}{|c|}{ Cerbat Mountains } \\
\hline $\mathrm{K}-1$ & $\begin{array}{l}\text { Intermittently active bajada. } \\
\text { Mostly fine-grained } \\
\text { materials. }\end{array}$ & $\begin{array}{l}\text { Vesicular } \mathrm{A}_{\mathrm{V}} \text { horizon. Weak B } \\
\text { horizon. Stage II K horizon. }\end{array}$ & $\mathrm{Q} 2 \mathrm{~b} /{ }^{2}$ & 74.9 & 75.9 & 75.4 & $0.94^{3}$ \\
\hline $\mathrm{K}-2 \mathrm{y}$ & $\begin{array}{l}\text { Active alluvial flood plain. } \\
\text { Mostly sands. }\end{array}$ & $\begin{array}{l}\text { No B horizon. Weak Stage I K } \\
\text { horizon. }\end{array}$ & $\mathrm{Q} 4^{2}$ & 88.5 & 96.7 & 92.6 & $0.99^{3}$ \\
\hline $\mathrm{K}-2 \mathrm{o}$ & $\begin{array}{l}\text { Isolated alluvial terrace, } 2-3 \\
\text { m above flood plain. }\end{array}$ & $\begin{array}{l}\text { Well-developed argillic B } \\
\text { horizon. Strong Stage I-II K } \\
\text { horizon. }\end{array}$ & $\mathrm{Q}^{2}$ & 24.3 & 14.8 & 19.6 & $0.09^{3}$ \\
\hline
\end{tabular}

${ }^{1}$ Full soil descriptions are given in Appendix 1.

${ }^{2}$ Correlated with the Mohave Mountain sequence on the basis of soil morphology (see text and Appendix 1).

${ }^{3}$ Calculated independently from Mohave Mountains and Dutch Henry Flats values.

Bachman and Machette (1977). Soil descriptions are given in Appendix 1.

Vegetation was measured for target sites that had sufficient areal extent and uniformity of geomorphic unit and lacked evidence of recent disturbances in May and June of 1985, representing about 42 years of recovery. Transects were placed parallel to each other in and out of each target site and oriented to maintain similar slope. Recovery of perennial vegetation was determined by comparing cover, density, and volume of shrubs taken from three $200 \mathrm{~m}^{2}$ belt transects $\left(600 \mathrm{~m}^{2}\right.$ total); two 200 $\mathrm{m}^{2}$ belt transects were measured in the Cerbat Mountains. Transect data was recorded in $20 \mathrm{~m}^{2}$ intervals to generate statistical information. Contiguous geomorphic surfaces were measured and potential edge effects (Johnson and others, 1976) were avoided.

The degree of recovery for each site was estimated using percentage similarity (PS) and 
correlation coefficient (CC) indices (Gauch, 1982). These indices allow a numerical comparison of the varying degrees of recovery observed in different sites. Three separate PS indices and one CC index were generated for each study area. The PS indices were calculated from cover data, density data, and the mean of the cover and density PS values. The PS index calculated from the mean of cover and density PS values ("combined PS value") avoids the bias that cover or density PS values alone may introduce against species with life-history strategies that may emphasize one over another. For example, species adapted to relatively stable environments commonly have low reproduction rates and relatively large size and species adapted to constant disturbance typically have high reproduction rates and relatively small size (Grime, 1979). Consequently, cover measurements may over-represent the former while density measurements may overrepresent the latter. Indices from volume data were not calculated because the increased spread in the data range due to the multiplication cover measurements by a height measurement would significantly reduce the importance of low stature vegetation. The one-sided Student's t-test $(>0.95)$ was used to detect significant differences in vegetation data in and out of each target site for each species. A principal components analysis (PCA) diagram was generated with cover data to determine indistinct relations among sites (Gauch, 1982).

\section{RESULTS}

\section{Correlation of Geomorphic Units}

To compare the degree of recovery of target sites, we correlated the geomorphic units on Dutch Henry Flats and in the Cerbat Mountains with the target sites in the Mohave Mountains into a framework that allows comparison of the edaphic characteristics of each unit. The geomorphic units underlying the sites in the Mohave Mountains (A and $\mathrm{B}$ series, fig. 1) were previously described by Wilshire and Reneau (1992) using the landform classification system developed by Bull (1974, 1991). We corroborated these designations (see table 2), which reflect a series of geomorphic units that are believed to be erosional in origin and not time-stratigraphic units (Wilshire and Reneau, 1992).

The sites on Dutch Henry Flats (C series, fig. 1) can be correlated with Q3a units in the Mohave Mountains (table 2). Both C-0 and C-1 have stage I to weak stage II calcic horizons (Appendix 1) and are located far enough from the source area in the Hualapai Mountains to disregard the Q3a criteria (table 1) not met by these sites; namely, the presence of cobbles and boulders and the evidence of bar/swale features (table 2). Smaller and slightly higher surfaces that show varnish on pebbles and stream-cut exposures of well-cemented calcic horizons have been preserved on the bajada near C0 and are probably correlative of Q2 units (table 1), which further suggests the adequacy of the Q3a designation. The sites on the eastern slope of the Cerbat Mountains (K series, fig. 1) are 400 to 600 $\mathrm{m}$ higher in elevation than those in the Mohave Mountains, receive runoff from a more extensive watershed, and are much farther from the controlling influence of the Colorado River on the regional base level (Wilshire and Reneau, 1992).

As a result of these factors and parent material differences, the correlation of geomorphic units in the Cerbat Mountains with those in the Mohave Mountains is more difficult. The youngest unit $\mathrm{K}-2 \mathrm{y}-\mathrm{is}$ a broad flood plain with no soil development (Appendix 1) and is correlated with Q4 units in the Mohave Mountains. The adjacent surface $\mathrm{K}-2 \mathrm{o}$ is $4 \mathrm{~m}$ higher than the channel and contains a well-developed argillic horizon nearly a meter in thickness with weak stage I carbonate deposited in the soil peds. The soil morphology suggests an age correlative with Q2 units despite the lack of calcic horizon development usually found in soils on Q2 units. Higher rainfall and lower temperatures and, to a lesser extent, differences in parent material, may be responsible for the lack of calcic horizon development (McFadden and Tinsley, 1985). K-1 can be correlated with a Q2b or Q3a unit. The site bears a soil with a much less pronounced argillic horizon than K-2o and a stage II calcic horizon (Appendix 1). There is no desert pavement, an important criterion for designation of Q2 units, on the east slope of the Cerbat Mountains. 


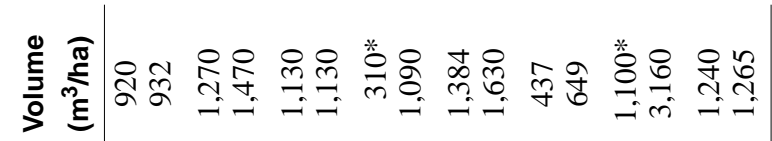

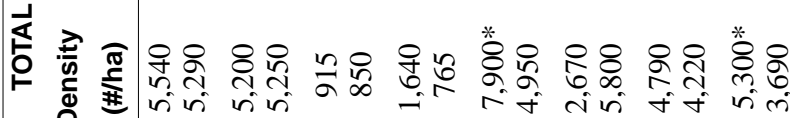

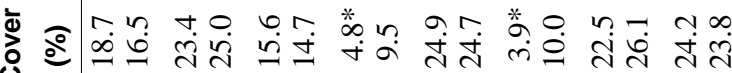

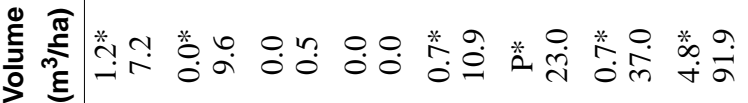

in

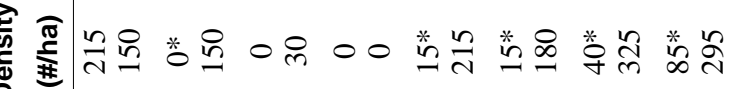

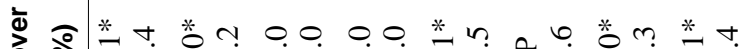

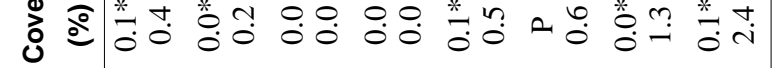

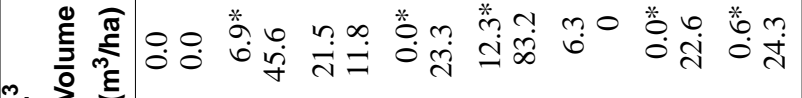
की

蛋 00 党

‡ ग0

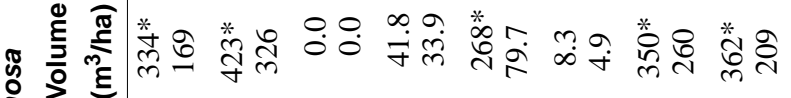
ริ สํำ

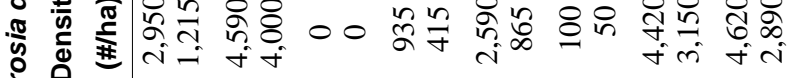
है

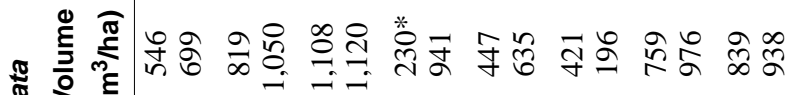

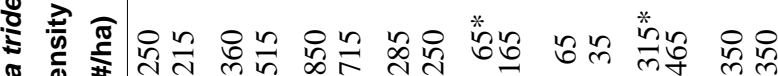

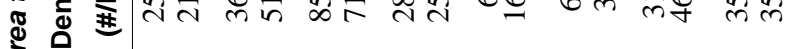
गें ஓ ล

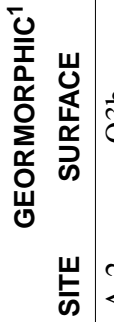
$\approx$

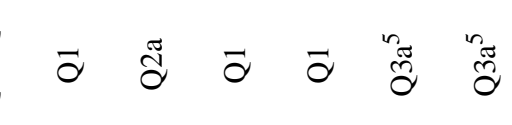

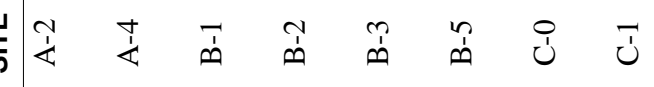

n
作

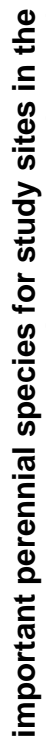

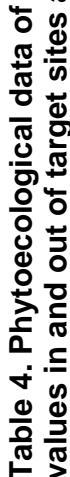

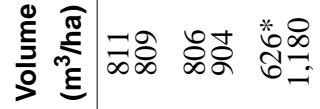

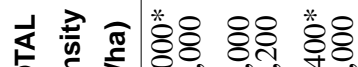

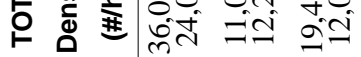

岁

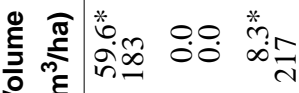

is

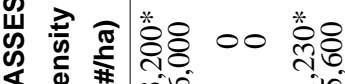

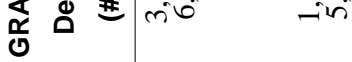

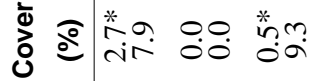

产

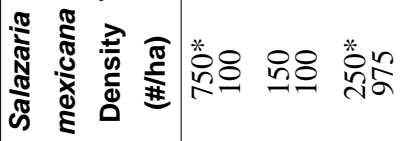

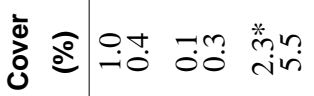

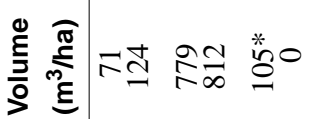

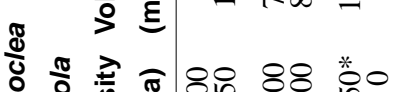

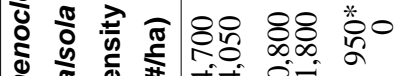

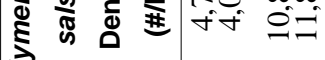

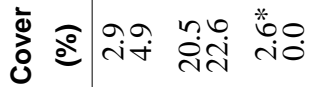

产 孚

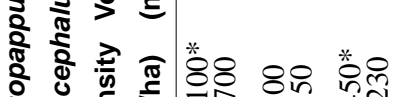

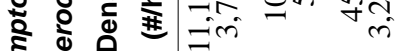

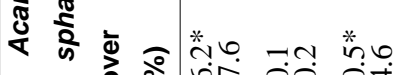

ํํㅇ

ฮ $ค$ ค คร คด

寊

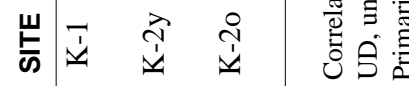




\section{Behavior of Perennial Vegetation}

Tables 3 and 4 present cover, density, and volume data for the most important species in and out of all target sites for the Mohave Mountains and Dutch Henry Flats (table 3) and the Cerbat Mountains (table 4). A complete set of vegetation data appears in Appendix 2. The widespread occurrence of these species allows for the analysis of their colonization behavior across varying geomorphic units, and their relative abundance imparts a high degree of statistical certainty to the results. For this discussion, species will be referred to as having responded negatively if they have not recovered to levels corresponding to predisturbance conditions or having responded positively if they are better represented in the target site than the adjacent control.

In the Mohave Mountains and on Dutch Henry Flats, Larrea, Krameria sp. (undifferentiated parvifolia and grayii) and Opuntia sp. have generally responded negatively to disturbance, while Ambrosia has generally responded positively. Statistically significant differences $(\mathrm{p}<0.05)$ in cover and density vary across the geomorphic units in no apparent pattern, but where statistically significant differences occur (table 3), the response of the species is always the same regardless of the geomorphic unit.

This does not appear to be the case for the major species in the Cerbat Mountains (table 4). Only perennial grasses, primarily Hilaria rigida, shows a clear (negative) response to disturbance independent of the geomorphic unit. Acamptopappus and to a lesser extent Salazaria show a statistically significant $(\mathrm{p}>0.95)$ shift in behavior. On K-2o, a relatively old geomorphic unit correlative of Q2 units, both species show a significantly negative response, but on $\mathrm{K}-1$, a unit correlative with Q2b/Q3a surfaces, both species show a statistically significantly positive response (Salazaria for density alone). Hymenoclea salsola shows a statistically significantly positive response on $\mathrm{K}-2 \mathrm{o}$ but its response is inconclusive on the other two Cerbat Mountain sites.

Depending on the site, eight other species show statistically significant negative responses and six species show statistically significant positive responses (table 5). Three species, Cercidium microphyllum, Encelia farinosa, and Coldenia canescens show statistically significant shifts in response. However, these conclusions are tentative because their occurrence is relatively limited and the cover and/or density of these may be undersampled.

\section{Recovery of Perennial Vegetation}

The revegetation observed in the target sites after 40 years is highly variable. The degree of recovery as indicated by percentage similarity values ranges from 24.3 to 98.9 percent for cover and 14.8 to 96.7 percent for density (table 2). Combined PS values range between 19.6 to 95.1 percent and CC values calculated from cover data range from 0.10 to 0.99 (table 2). In our experience, PS values less than 60 percent probably indicate distinctly different assemblages. Using this measure, the only target sites that are dissimilar enough to be considered not recovered are B-3 and B-5, both old Q1 units showing extreme erosion, and $\mathrm{K}-2$, the oldest unit measured in the Cerbat Mountains (table 2). Alternatively, PS values 90 percent and above indicate virtually identical assemblages (Gauch, 1982). Therefore, B-1, a Q1 unit bearing an almost monospecific stand of Larrea, and $\mathrm{K}-2 \mathrm{y}$, an active alluvial channel bearing an almost monospecific stand of Hymenoclea, can be considered fully recovered.

\section{Geologic Age and Recovery}

The relation between geomorphic units of increasing age and the degree of recovery as expressed by PS or CC values is presented in figure 2. The length of the horizontal bars in the diagram reflects the certainty to which a geomorphic unit can be classified according to Bull's $(1974,1991)$ criteria and the correlation of units in the Dutch Henry Flats and Cerbat Mountains made in this study. In addition, the relative horizontal positioning of the bars reflects slight differences in soil morphology. For example, although both B-1 and B-3 are designated as Q1 units, B-3 exhibits a better developed calcic horizon (table 2) indicative of greater age (Bachman and Machete, 1977). 
Table 5. Response to disturbance of secondary species as indicated by statistically significant $(p<0.05)$ differences of cover and(or) density in and out of target sites. See Tables 3 and 4 for information on major species and Appendix 2 for complete vegetation data.

\begin{tabular}{|c|c|c|}
\hline SPECIES & TARGET SITE & PHYTOECOLOGICAL MEASURE $^{1}$ \\
\hline \multicolumn{3}{|c|}{ SPECIES NOT RECOVERED FROM DISTURBANCE (-) } \\
\hline Fouquieria splendens & B-5, C-0 & $\mathrm{CD}$ \\
\hline Krameria sp. ${ }^{2}$ & $\mathrm{~K}-2 \mathrm{o}$ & $\mathrm{CD}$ \\
\hline Ephedra sp. ${ }^{3}$ & B-3 & $\mathrm{CD}$ \\
\hline Agave deserti & B-3 & $\mathrm{D}$ \\
\hline Yucca bacata & $\mathrm{K}-2 \mathrm{o}$ & $\mathrm{CD}$ \\
\hline Stephanomeria pauciflora & B-5 & $\mathrm{D}$ \\
\hline Acamptopappus sphaerocephalus ${ }^{1}$ & B-3 & $\mathrm{CD}$ \\
\hline Baileya multiradiata & B-5 & $\mathrm{CD}$ \\
\hline Argemone corymbosa & B-5 & $\mathrm{CD}$ \\
\hline Sphaeralcea ambigua & B-5 & $\mathrm{CD}$ \\
\hline \multicolumn{3}{|c|}{ SPECIES ENHANCED AFTER DISTURBANCE (+) } \\
\hline Lycium sp. ${ }^{4}$ & B-3 & $\mathrm{CD}$ \\
\hline Opuntia basilaris 5 & A-2, B-3 & $\mathrm{C}$ \\
\hline Cassia covesii & B-2 & $\mathrm{D}$ \\
\hline Gutierrezia sarothrae $^{6}$ & $\mathrm{~K}-2 \mathrm{o}$ & $\mathrm{CD}$ \\
\hline Opuntia whipplei & $\mathrm{K}-2 \mathrm{o}$ & $\mathrm{CD}$ \\
\hline Eriogonum fasciculatum & $\mathrm{K}-2 \mathrm{o}$ & $\mathrm{CD}$ \\
\hline \multicolumn{3}{|c|}{ SPECIES SHIFTING BEHAVIOR } \\
\hline Encelia farinosa & A-2 (-); B-5 (-); B-3 (+) & B-5, D; A-2 and B-3, CD \\
\hline Coldenia canescens & B-5 C (-); B-3 (+) & $\mathrm{CD}$ \\
\hline Cercidium microphyllum $^{7}$ & B-5 (-); A-2 (+) & $\mathrm{B}-5, \mathrm{D} ; \mathrm{A}-2, \mathrm{CD}$ \\
\hline
\end{tabular}

${ }^{1} \mathrm{CD}$, both cover and density; C, cover only; $\mathrm{D}$, density only.

${ }^{2}$ See Tables 3 and 4 . Krameria includes both K. parviflora and K. grayii.

${ }^{3}$ Includes Ephedra viridis and E. trifurca. $\quad{ }^{4}$ Includes Lycium andersonii and L. torreyi.

${ }^{5}$ See Table 3. O. basilaris is the only member of the genus found in the Mohave Mountains which responds positively to disturbance.

${ }^{6}$ Includes a small amount of Chrysothamnus paniculatus. $\quad{ }^{7}$ See section on "Behavior of Perennial Species."

The strongest pattern in figure 3 indicates a higher variability in the recovery of vegetation on older surfaces than the recovery of vegetation on younger surfaces. The target sites on Q1 units in the Mohave Mountains have combined PS values ranging between 22.7 percent for B-5, 58.1 percent for B-3, and 95.1 percent for B-1 (table 2). The youngest geomorphic unit (Q3b) shows a combined PS value of 69.0 percent (A-2) while relatively older geomorphic units (Q3a/Q2 and Q2) plot relatively close (fig. 3) with combined PS values of 86.0 and 75.6 percent (A-4 and B-2), respectively.

The target sites on Dutch Henry Flats and in the Cerbat Mountains plot in similar positions as the target sites in the Mohave Mountains with geomorphic units of comparable age. Combined PS values for $\mathrm{C}-0$ and $\mathrm{C}-1$ (78.7 and 81.7 percent, respectively) are similar to the values generated from other sites on or correlated with Q3a units (A4, 86.0 percent, and K-1, 75.4 percent).

A second pattern is indicated by the analysis of the target sites in the Cerbat Mountains independent of the other sites studied. The positions of the three target sites (K series; fig. 3) suggest an inverse relation between the degree of recovery and relative geomorphic age. This relation is also evident, but to a lesser degree, in the positions of the target sites in the Mohave Mountains. The positions of A-2 and B-1 on figure 2 reduce the certainty of this assertion. The principal components analysis 


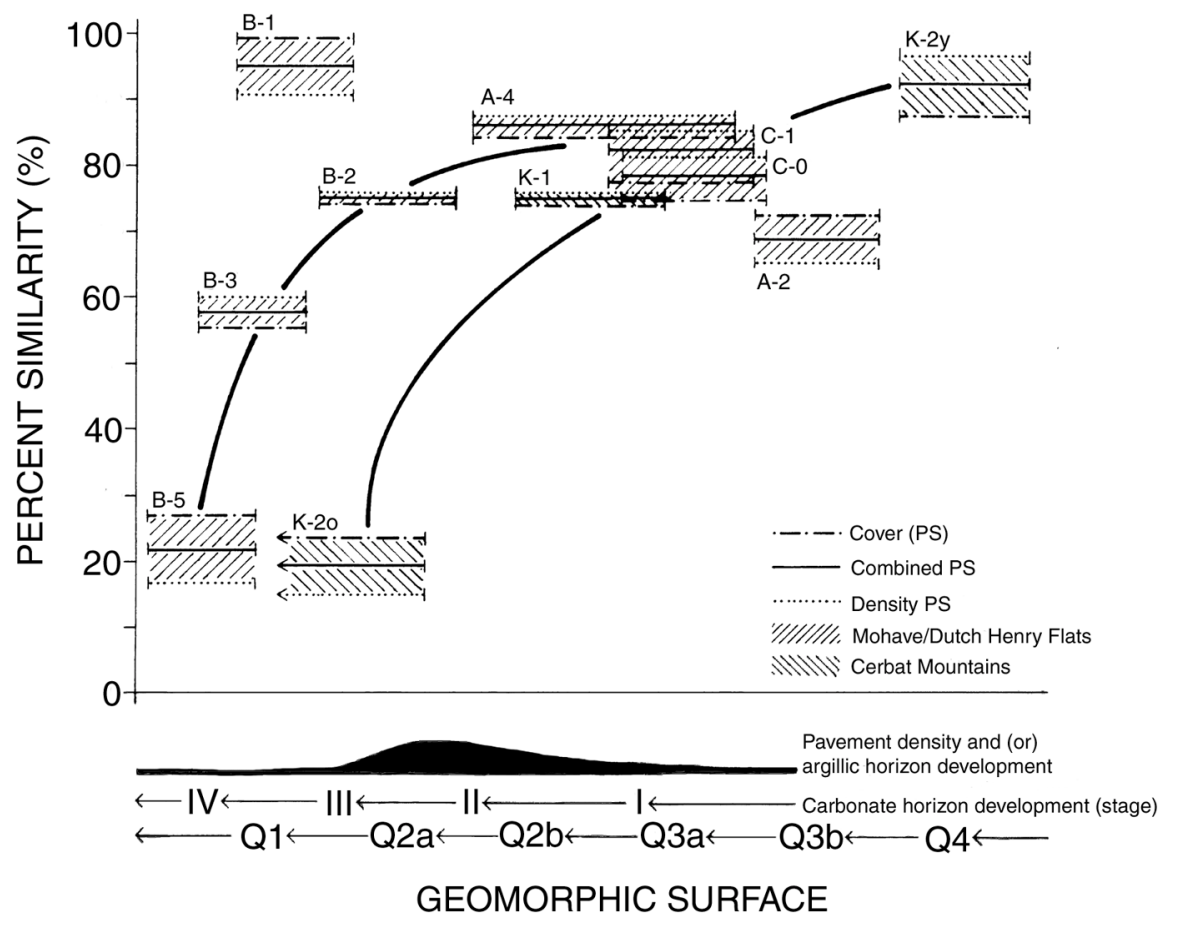

Figure 3. The amount of geomorphic development versus recovery of perennial vegetation (as measured using percent similarity) for target sites in the Mohave and Cerbat Mountains, western Arizona. The heavy lines represent a hypothetical recovery path.

diagram (fig. 4), generated with cover data for sites in the Mohave Mountains and Dutch Henry Flats, further illustrates the pattern of increasing variability with the type of geomorphic surface. The variability of revegetation on Q1 units is much greater than that on younger surfaces; for example, all Q3 units plot very close together when compared to other units. The variability of revegetation on Q1 units is partially explained by the high degree of dissimilarity between undisturbed Q1 sites in comparison with that between younger sites. Compositions of predisturbance vegetation on Q1 units are also much more variable than other units.

\section{DISCUSSION}

\section{Blading Disturbance and Vegetation Response}

Uniform blading of up to $0.2 \mathrm{~m}$ of surface material from different geomorphic units has resulted in different patterns of revegetation in the
Mojave Mountains, Dutch Henry Flats, and the Cerbat Mountains. The patterns of vegetation recovery can be interpreted both as responses to a disturbance of varying severity as well as than as a response to the age of geomorphic surfaces. Differences in soil characteristics, the life-history strategies of the species present, and annual variations in rainfall (Beatley, 1980) dictate the degree of recovery manifested on each site. The soil characteristics that affect the establishment, growth, and reproduction of species vary from surface to surface. These characteristics (table 6) will be referred to as functional edaphic characteristics, as opposed to edaphic characteristics with no significant bearing on revegetation. As noted in table 6, functional edaphic characteristics are closely related to the age of geomorphic surfaces.

The effects of disturbance on revegetation vary according to the functional edaphic characteristics of each unit and how those characteristics are modified by the disturbance. For example, Q4 surfaces are composed of unweathered alluvium receiving intermittent but fairly frequent pulses of overland flow, which periodically removes existing 


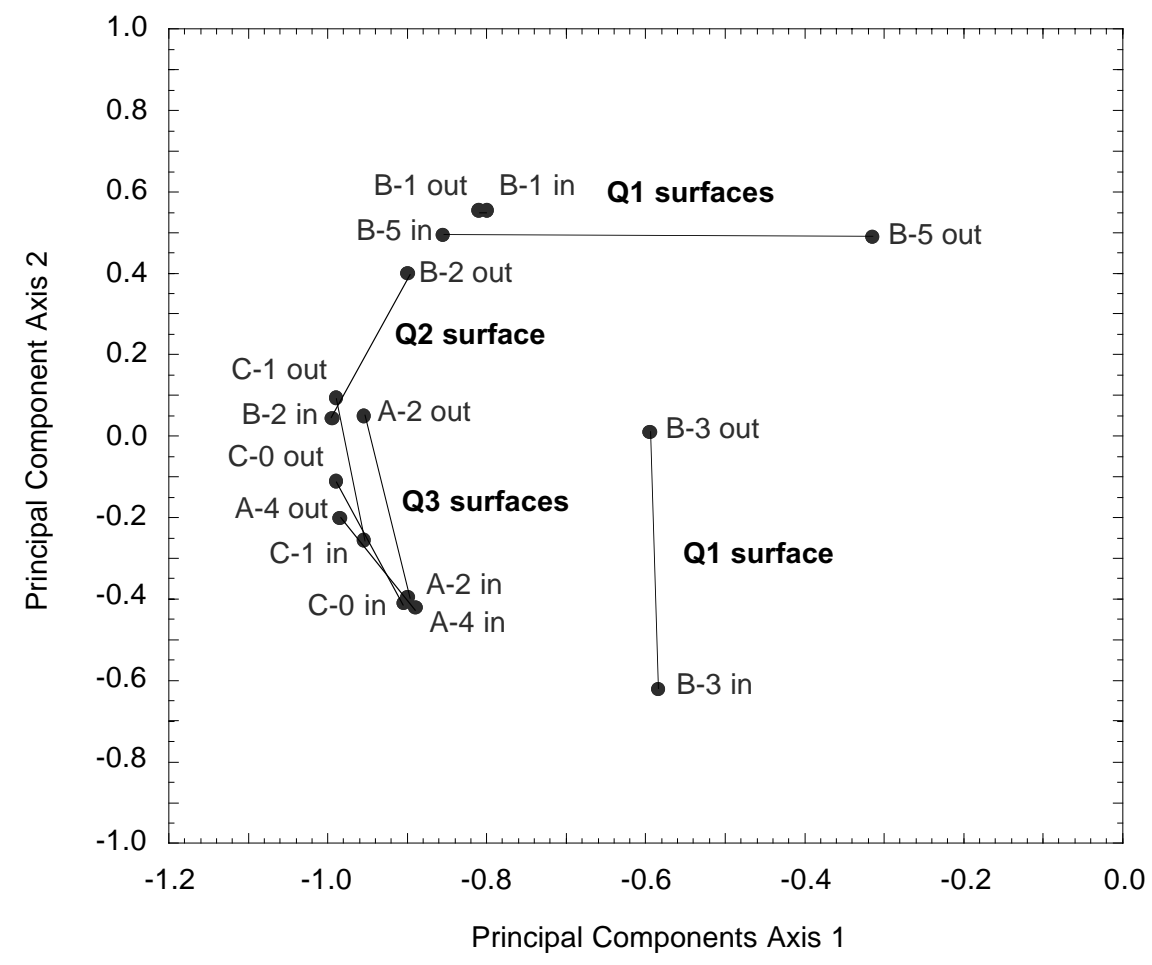

Figure 4. Principal-components analysis for sites in the Mohave Mountains and Dutch Henry Flats. The analysis is based on standardized cover data (see Appendix 2).

vegetation and rearranges and(or) replenishes the seedbank. The functional geomorphic characteristics of this unit are not significantly altered by blading, and blading Q4 surfaces has effects similar to those of natural floods. Conversely, A horizons on Q3 units are richer in nutrients and contain a better-established seedbank. Blading this unit, consequently, will have a greater effect on revegetation than the blading of a $\mathrm{Q} 4$ unit.

The severity of disturbance during blading is greater for Q2 units than for Q3 and Q4 units. The functional geomorphic characteristic of Q2 units that is most obvious is the presence of desert pavement. Virtually no perennial species are able to grow in areas with well-developed pavements, although the size of the interstices between surface particles varies across a typical Q2 unit and patches of vegetation occur. The vesicular $A_{v}$ horizon controls infiltration to the extent that less moisture penetrates these surfaces, with concomitant decreases in perennial vegetation cover (McDonald and others, 1995; McAuliffe and McDonald, 1995). The argillic horizon occurs within as little as $80 \mathrm{~mm}$ of the surface of Q2 surfaces and could be exposed by blading. Blading could therefore have a significant positive effect on the moisture dynamics of the disturbed surface, allowing greater infiltration and presumably more growth of perennial vegetation.

The effect of disturbance caused by blading on Q1 units can vary over a large range depending on the thickness and nature of the material overlying the petrocalcic horizon. Thicknesses can range from 0-2.0 m, with surface exposures of laminar, Stage IV carbonate at some sites. Consequently, blading may have as little effect as disrupting the soil surface or as drastic an effect as complete removal of the surface horizons.

A partial table of the expected effects of blading on the functional edaphic characteristics of each unit is presented in table 6. The table is considered partial because of the lack of data relating vegetation dynamics to geomorphology in arid regions. The assumption of uniform blading made throughout this study is difficult to justify. Field evidence suggests that the bulldozer operator 
Table 6. A partial list of the possible effects of blading on selected functional edaphic characteristics in the eastern Mojave Desert.

\begin{tabular}{|c|c|c|c|c|c|}
\hline & & \multicolumn{4}{|c|}{$\mathrm{UNIT}^{1}$} \\
\hline \multicolumn{2}{|c|}{ SURFACE DESIGNATION: } & Q4 & Q3 & Q2 & Q1 \\
\hline \multicolumn{2}{|c|}{$\begin{array}{l}\text { FUNCTIONAL EDAPHIC } \\
\text { CHARACTERISTICS OF } \\
\text { GEOMORPHIC SURFACES }\end{array}$} & $\begin{array}{l}\text { ACTIVE }^{2} \\
\text { CHANNEL }\end{array}$ & $\begin{array}{c}A_{v}^{2} \\
\text { HORIZON }\end{array}$ & $\begin{array}{l}\text { PAVEMENT, } \mathbf{A}_{v}{ }^{2} \\
\text { AND ARGILLIC } \\
\text { HORIZONS }\end{array}$ & $\begin{array}{c}\text { PETROCALCIC } \\
\text { HORIZON }\end{array}$ \\
\hline \multicolumn{6}{|c|}{$\begin{array}{l}\text { EXPECTED DISTURBANCE } \\
\text { SEVERITY }\end{array}$} \\
\hline \multirow[t]{5}{*}{$\begin{array}{l}\text { HORIZONS AT } \\
\text { THE SURFACE }\end{array}$} & $\begin{array}{l}\text { NITROGEN }^{3} \\
\text { CONTENT }^{2}\end{array}$ & none to slight ${ }^{6}$ & severe & slight to very severe ${ }^{7}$ & none to very severe ${ }^{8}$ \\
\hline & SEEDBANK & none to slight ${ }^{6}$ & severe & slight to very severe ${ }^{7}$ & none to very severe ${ }^{8}$ \\
\hline & ROOT-CROWNS ${ }^{4}$ & none to slight ${ }^{6}$ & slight to severe & slight to very severe ${ }^{7}$ & none to very severe ${ }^{8}$ \\
\hline & INFILTRATION & none & slight & very severe & none to very severe ${ }^{8}$ \\
\hline & $\begin{array}{l}\text { RUNOFF AND } \\
\text { EROSION }\end{array}$ & none & slight & very severe & none to very severe ${ }^{8}$ \\
\hline \multirow[t]{3}{*}{$\begin{array}{l}\text { SUBSURFACE } \\
\text { HORIZONS }\end{array}$} & $\begin{array}{l}\text { ROOTING } \\
\text { LIMITATIONS }\end{array}$ & none & none & severe to very severe & none to very severe ${ }^{8}$ \\
\hline & $\begin{array}{l}\text { MOISTURE } \\
\text { RETENTION }\end{array}$ & none & none & very severe & none to very severe ${ }^{8}$ \\
\hline & THROUGHFLOW & none & none & slight to very severe & none to very severe ${ }^{8}$ \\
\hline \multicolumn{2}{|c|}{$\begin{array}{l}\text { EXPECTED RATE OF VEGETATION } \\
\text { RECOVERY }\end{array}$} & fast & slow & slow to very slow & fast to very slow \\
\hline \multicolumn{2}{|c|}{ OBSERVED PS VALUES ${ }^{5}$} & 92.6 & $69.0-86.0$ & $19.6-74.9$ & $22.7-95.1$ \\
\hline $\begin{array}{l}{ }^{1} \text { Includes units corr } \\
{ }_{2} \text { Most important ed } \\
{ }^{3} \text { See Garcia-Moya } \\
{ }^{4} \text { Indicated range al } \\
\text { crowns survive distl } \\
{ }^{5} \text { Combined PS valu } \\
{ }^{6} \text { Range dependent } \\
{ }^{7} \text { Range dependent } \\
{ }^{8} \text { Range dependent }\end{array}$ & $\begin{array}{l}\text { ted with the Mohave Mo } \\
\text { hic characteristics determ } \\
\text { McKell (1970) for a dis } \\
\text { takes into account the ch } \\
\text { ance (observed on most t } \\
\text { see Table } 2 \text {. } \\
\text { lood frequency. } \\
\text { density of pavement. } \\
\text { hickness of material ove }\end{array}$ & $\begin{array}{l}\text { Intain sequence. } \\
\text { ning the unit's uniq } \\
\text { ussion of nitrogen i } \\
\text { mposition of pre-di } \\
\text { rget sites studied). }\end{array}$ & $\begin{array}{l}\text { ess in controlling } \mathrm{r} \\
\text { pper soil horizons. } \\
\text { rbance species likel }\end{array}$ & $\begin{array}{l}\text { egetation. } \\
\text { to be growing on site. Ass }\end{array}$ & umes the majority of root- \\
\hline
\end{tabular}

ceased blading where vegetation was already absent. This appears to be the case on several patches of well-developed pavement on the surface of B-2 and likely in several areas of A-4. Incomplete blading changes the patch geometry and therefore affects the proximity to new seed sources as well as invalidating the assumption that the vegetation was in fact disturbed.

\section{Patterns of Recovery}

Two patterns of recovery dictated by geomorphic age are apparent for the study sites. The pattern of increased variability on older surfaces is the most obvious (fig. 3). The inverse pattern, which suggests an inverse relation between the degree of vegetation recovery and geomorphic age, is less apparent (fig. 3). These patterns are in accord with observations on the effects of blading on functional edaphic characteristics.

The rate of recovery would be expected to be most rapid on Q4 units because species occupying sites in washes are adapted to relatively frequent disturbance by flooding. In addition, desert washes receive additional moisture, which presumably could increase the rate of plant recovery. The active channels in the Cerbat Mountains (K-2y) completely recovered in less than 42 years. The rate of recovery would be expected to be slower for units of increasing geomorphic age. Q3 units develop an $A_{v}$ horizon, which presumably is richer 
in organic material and nutrients, and the oldest Q3 units show development of desert pavement (table 1). Channel density decreases on each progressively older unit, creating a more stable surface on which species less tolerant of disturbance may colonize as well as reducing the amount of water running onto the surface to supplement rainfall. Consequently, these surfaces have recovered less than Q4 surfaces.

Q2 units are more stable, but increasing age is associated with denser desert pavement, thicker $A_{v}$ horizons, and better developed argillic and calcic horizons, which retard root penetration and decrease water infiltration. The variation would be expected to be greater on Q2 units than Q3 units due to the patchy nature of desert pavement and the various mechanisms by which soil horizons influence plant growth. Blading of K-2o resulted in the removal of the $A_{v}$ horizon and, in several areas, exposure of the well-developed argillic horizon. Apparently, the lack of recovery observed at K-2o (table 2) stems, in part, from the inability of some species to grow on an exposed argillic horizon. The blading of B-2 was discontinuous and consequently the amount of recovery is greater than would be expected if the surface had been uniformly disturbed.

The variation in the rate of recovery on Q1 units was expected to be larger than that of any of the units studied. The vegetation established on Q1 units is patchy, with the large spatial variation related to whether loose substrate overlies the nearsurface petrocalcic horizons. Undisturbed units with very little or no material overlying the petrocalcic horizon bear virtually no vegetation and the rate of recovery may be inapplicable. If vegetation is established and blading totally removes loose substrate, the site will not be expected to recover until the substrate is reestablished. Blading a series of Q1 units with increasingly thicker material overlying the petrocalcic horizon should result in slower rates of recovery, until the overlying material is thick enough not to be a limiting factor.

The recovery on site B-1 (table 2) is apparently caused entirely by root-crown sprouting. Interfluves between the Q1 ridges crossed by the target site are dominated by Ambrosia. Based on the response of this species elsewhere, Ambrosia would be expected to establish in the target site (Prose and others, 1987); however, no individuals could be found on the entire disturbed Q1 surface. Evidently, blading left virtually every Larrea root-crown intact, which effectively prevented colonization by Ambrosia.

\section{Successional Implications}

The inverse pattern suggested in figure 3 implies successional convergence (Horn, 1975; Webb and others, 1987, 1988), which indicates a change of vegetation from sites with different species compositions toward a uniform composition or regional climax. Usually, the term succession is applied to species or assemblage changes in wetter climates with completely biotic control, but here the term is used to denote compositional change in a system where environmental stress has strongly influenced diversity and niche separation. Although the concept has biological (Pickett, 1976) and statistical (Horn, 1975) support, successional convergence has not been well documented (McIntosh, 1980) and would be considered a somewhat unusual occurrence due to the variety and complexity of the spatial and temporal gradients that create any given landscape mosaic (Whittaker and Levin, 1977).

The geomorphic surfaces discussed in this paper are created by base-level changes caused by climatic shifts and(or) tectonic activity (Wilshire and Reneau, 1992). The events causing base-level changes have occurred under different sets of environmental conditions, and until more complete paleoecological information is known, it is safe to assume that the processes that created each unit are relatively unique. Consequently, the sequence of landform evolution implied by the geomorphic units present in the Mohave Mountains cannot be viewed as the result of an ongoing, continuous process, and "convergence" can only be used as a term indicating the relation between vegetation compositions of existing units rather than as a term indicating vegetation change through time.

However, successional convergence can be investigated on units created during the Holocene (Q3, Q4; table 1), where climate and tectonic activity can be assumed to be relatively constant (however, see Cole and Webb, 1985). The principal-components analysis (fig. 4) shows a pattern among the younger units which indicates 
successional convergence. The disturbed sites on target sites C-0, A-2, and A4 plot extremely close to each other with respect to their controls. The target sites on these Q3 units were scraped of their organic horizons, resulting in surfaces functionally similar to Q4 units. A convergent pattern emerges from figure 3 if disturbed sites are considered similar to undisturbed Q4 units. However, the assumption of disturbance "resetting the successional clock back to zero" (Whittaker and Levin, 1977, p. 132) is not necessarily valid and the small number of sampled sites precludes any definitive conclusions.

\section{Species Revegetation Strategies}

For this study, we hypothesized that uniform disturbance on two geomorphically-distinct units bearing similar compositions of vegetation may result in different revegetation patterns. The data generated by this study cannot be applied directly to test this hypothesis. However, consideration of the possible mechanisms leading to variability in colonizing assemblages is heuristically valuable. Two mechanisms - one physical and one biological - can create variability in revegetation among different-age geomorphic surfaces. Geomorphic surfaces have different sets of functional geomorphic characteristics which are effected differently by disturbance and elicit different vegetation responses. Also, the variability in revegetation occurs because one or more species in the assemblage have a life-history strategy that emphasizes variable response among surviving individuals or incoming seedlings.

The biological mechanism influenced by lifehistory strategies is supported by the occurrence of species that show behavior shifts independent of geomorphic surface (tables 4 and 5). Encelia farinosa and Coldenia canescens show no pattern of significant behavior shift according to differences in unit designation or the differences in functional geomorphic characteristics within each unit. There do appear to be intraspecific associations between Acamptopappus and Salazaria and Encelia and Coldenia; both pairs significantly change their responses in the same direction over the same units. For example, both Acamptopappus and Salazaria shift from a negative response on K20 to a positive response on K-1. These intraspe- cific associations could be the result of similar competitive-avoidance strategies or indicate geomorphic control on species behavior.

The most striking example of the importance of life-history strategy to response to disturbance irrespective of geomorphic unit is the ability of several species to root-crown sprout. As previously discussed, nearly monospecific stands of Larrea in and out of target site B-1 and the abundance of Ambrosia nearby strongly suggests that surviving root-crowns completely controlled the revegetation of this site. Similar root-crown survival and subsequent dominance may account for the apparent positive response of Cercidium to blading on target site A-2. Several individuals of $1.4 \mathrm{~m}$ or more in height occurred inside the target site and their large size gave the species an inordinately high dominance within the transects. Outside of the target site, no plants occurred in the transects although very large (4-5 $\mathrm{m}$ tall) individuals were scattered throughout the area. Consequently, the apparent behavior shift recorded for this species (table 5) may be the result of undersampling.

\section{ACKNOWLEDGMENTS}

The authors would like to thank Susan Metzger, Howard Wilshire, and Doug Prose for their invaluable field assistance and manuscript comments. This work was funded by the U.S. Army Research Office, contract no. 104-84. The manuscript was critically reviewed by Wilshire, David Miller, and Raymond M. Turner of the U.S. Geological Survey.

\section{LITERATURE CITED}

Bachman, G.O., and Machette, M.N., 1977, Calcic soils and calcretes in the southwestern United States: U.S. Geological Survey, Open-File Report, 77-794, 163 pp.

Beatley, J.C., 1976, Vascular plants of the Nevada Test Site and central-southern Nevada: Springfield, Virginia, National Technical Information Center, TID-26881, 308 pp. 
Beatley, J.C., 1980, Fluctuations and stability in climax shrub and woodland vegetation of the Mojave, Great Basin, and Transition Deserts of southern Nevada: Israel Journal of Botany, v. 28, p. 149-168.

Bischoff, M.C., 2000, The Desert Training Center/ California-Arizona maneuver area, 1942-1944: Historical and archaeological contexts: Tucson, Arizona, Statistical Research, Inc., Technical Series $75,145 \mathrm{pp}$.

Brown, D.E. and Lowe, C.H., 1980, Biotic communities of the Southwest: U.S. Forest Service General Technical Report RM-78, 1 sheet, scale $1: 1,000,000$.

Bull, W.B., 1974, Geomorphic tectonic analysis of the Vidal region, in Information concerning geology and seismology, Vidal Nuclear Generation Station, Vol. III, Appendix 2.5B, 66 pp. Southern California Edison Co.

Bull, W.B., 1991, Geomorphic responses to climatic change: New York, Oxford University Press, 326 p.,

Cole, K.L., and Webb, R.H., 1985, Late Holocene vegetation changes in Greenwater Valley, Mojave Desert, California: Quaternary Research, v. 23, p. 227-235.

Drury, W.H., and Nisbet, I.C.T., 1973, Succession: Journal of the Arnold Arboretum, Harvard University, v. 54, p. 331-368.

Garcia-Moya, E., and McKell, C.M., 1970, Contribution of shrubs to the nitrogen economy of a desert-wash plant community: Ecology, v. 51, p. 81-88.

Gauch, H.G., Jr., 1982, Multivariate analysis in community ecology: Cambridge, Cambridge University Press, 298 p.

Grime, J.P., 1979, Plant strategies and vegetation processes: New York, John Wiley and Sons, 222 p.

Horn, H.S., 1975, Markovian properties of forest succession, in Cody, M.L., and Diamond, J.M., (editors), Ecology and evolution of communities: Cambridge, Massachusetts, Harvard University, Belknap Press, p. 196-211.

Howard, K.A., Nielson, J.E., Wilshire, H.G., Nakata, J.K., Goodge, J.W., Reneau, S.L., John, B. E., and Hansen, V.L., 1990, Preliminary geologic map of the Mohave Mountains area, Mohave County, western Arizona: U.S. Geological Survey Open-File Report 90-0684, 1 sheet, scale 1:48,000.

Howard, K.A., Nielson, J.E., Wilshire, H.G., Nakata, J.K., Goodge, J.W., Reneau, S.L., John, B. E., and Hansen, V.L., 2000, Preliminary geologic map of the Mohave Mountains area, Mohave County, western Arizona: U.S. Geological Survey Map I-2308, 1 sheet, scale 1:48,000.

Hunt, C.B., 1972, Geology of soils: San Francisco, W.H. Freeman and Company, $343 \mathrm{p}$.
Johnson, H.B., Vasek, F.C., and Yonkers, T., 1976, Productivity, diversity, and stability relationships in Mojave Desert roadside vegetation: Bulletin of Torrey Botanical Club, v. 102, p. 106-115.

Karpiscak, M.M., 1980, Secondary succession of abandoned field vegetation in southern Arizona: Tucson, Arizona, unpublished Ph.D dissertation, University of Arizona, $219 \mathrm{p}$.

Kay, B.L., and Graves, W.L., 1980, History of revegetation studies in California deserts, in Webb, R.H., and Wilshire, H.G. (editors), Environmental effects of off-road vehicles: New York, SpringerVerlag Publishing, p. 315-324.

Lathrop, E.W., 1983, Recovery of perennial vegetation in military maneuver areas, in Webb, R.H., and Wilshire, H.G. (editors), Environmental effects of off-road vehicles: New York, Springer-Verlag Publishers, p. 153-166.

Lathrop, E.W., and Rowlands, P.G., 1983, Plant ecology in deserts - An overview, in Webb, R.H., and Wilshire, H.G. (editors), Environmental effects of off-road vehicles: New York, Springer-Verlag Publishers, p. 113-152.

Lovich, J.E. and Bainbridge, D., 1999, Anthropogenic degradation of the southern California desert ecosystem and prospects for natural recovery and restoration: Environmental Management, v. 24, p. 309-326.

McAuliffe, J.R., 1991, Demographic shifts and plant succession along a late Holocene soil chronosequence in the Sonoran Desert of Baja California: Journal of Arid Environments, v. 20, p. 165-178.

McAuliffe, J.R., 1994, Landscape evolution, soil formation, and ecological patterns and processes in Sonoran Desert bajadas: Ecological Monographs, v. 64, p. 111-148.

McAuliffe, J.R., and McDonald, E.V., 1995, A piedmont landscape in the eastern Mojave Desert: Examples of linkages between biotic and physical components, in Reynolds, R.E., and Reynolds, J. (editors), Ancient surfaces of the east Mojave Desert: San Bernardino County Museum Association Quarterly, v. 42, no. 3, p. 53-63.

McDonald, E.V., McFadden, L.D., and Wells, S.G., 1995, The relative influences of climate change, desert dust, and lithologic control on soilgeomorphic processes on alluvial fans, Mojave Desert, California: Summary of Results, in Reynolds, R.E., and Reynolds, J. (editors), Ancient surfaces of the east Mojave Desert: San Bernardino County Museum Association Quarterly, v. 42, no. 3, p. 35-42. 
McFadden, L.D., and Tinsley, J.C., 1985, Rate and depth of pedogenic-carbonate accumulation in soils Formulation and testing of a compartment model: Geological Society of America, Special Paper 203, p. 23-42.

McIntosh, R.P., 1980, The relationship between succession and the recovery process in ecosystems, in Cairns, J. (editor), The recovery process in damaged ecosystems: Ann Arbor, Michigan, Ann Arbor Science Publishers, Inc., p. 11-62.

Mueller, C.H., 1940, Plant succession in the LarreaFlourensia climax: Ecology, v. 21, p. 206-212.

Pickett, S.T.A., 1976, Succession: an evolutionary interpretation: American Naturalist, v. 110, no. 971, p. 107-119.

Prose, D.V., 1985, Persisting effects of armored military maneuvers on some soils of the Mojave Desert: Environmental Geology and Water Science, v. 7, p. 163-170.

Prose, D.V., and Metzger, S.K., 1985, Recovery of soils and vegetation in World War II base camps, Mojave Desert: U.S. Geological Survey Open-File Report 85-234, $30 \mathrm{pp}$.

Prose, D.V., Metzger, S.K., and Wilshire, H.G., 1987, Effects of substrate disturbance on secondary plant succession; Mojave Desert, California: Journal of Applied Ecology, v. 24, p. 305-313.

Romney, E.M., Wallace, A., and Childress, J.D., 1971, Revegetation problems following nuclear testing activities at the Nevada Test Site: Proceedings of the Third National Symposium on Radio-ecology, Oak Ridge, Tennessee, p. 1015-1022.

Sellers, W.D., Hill, R.H., and Sanderson-Rae, M., 1985, Arizona climate: Tucson, Arizona, University of Arizona Press, $143 \mathrm{p}$.

Shreve, F., 1942, The desert vegetation of North America: Botanical Review, v. 8, p. 195-246.

Soil Survey Staff, 1975, Soil taxonomy — a basic system of soil classification for making and interpreting soil surveys: U.S. Department of Agriculture, Handbook no. 436.

Sulenski, R.J., 1972, The natural revegetation of mine sites in the Las Vegas Valley and the feasibility of allowing the free use collection of cacti and other desert plants: Las Vegas, Nevada, Bureau of Land Management Report 7383-3042-5380 (N-053), 41 p.

Vasek, F.C., 1983, Plant succession in the Mojave Desert: Crossosoma, v. 9, p. 1-23.
Vasek, F.C., Johnson, H.B., and Brum, G.D., 1975a, Effects of power transmission lines on vegetation in the Mojave Desert: Madrono, v. 23, p. 114-130.

Vasek, F.C., Johnson, H.B., and Eslinger, D.H., 1975b, Effects of pipeline construction on creosote bush scrub vegetation of the Mojave Desert: Madrono, v. 23, p. 1-13.

Vasek, F.C., and Lund, L.J., 1980, Soil characteristics associated with a primary succession on a Mojave Desert dry lake: Ecology, v. 61, no. 5, p. 1013-1018.

Webb, R.H., and Wilshire, H.G., 1979, Recovery of soils and vegetation in a Mojave Desert ghost town, Nevada, U.S.A.: Journal of Arid Environments, v. 3, p. 291-303.

Webb, R.H., and Newman, E.B., 1982, Recovery of soils and vegetation in Mojave Desert ghost towns: Environmental Conservation, v. 9, no. 3, p. 245-248.

Webb, R.H., Wilshire, H.G., and Henry, M.A., 1983, Natural recovery of soil and vegetation following human disturbance, in Webb, R.H., and Wilshire, H.G. (eds.), Environmental effects of off-road vehicles: New York, Sprinter-Verlag Publishers, p. 279-302.

Webb, R.H., Steiger, J.W., and Wilshire, H.G., 1986, Recovery of compacted soils in Mojave Desert ghost towns: Soil Science Society of America Journal, v. 50, p. 1341-1344.

Webb, R.H., Steiger, J.W., and Turner, R.M., 1987, Dynamics of Mojave Desert shrub vegetation in the Panamint Mountains: Ecology, v. 50, p. 478-490.

Webb, R.H., Steiger, J.W., and Newman, E.B., 1988, The effects of disturbance on desert vegetation in Death Valley National Monument, California: U.S. Geological Survey Bulletin 1793, 103 p.

Wells, P.V., 1961, Succession in desert vegetation in streets of a Nevada ghost town: Science, v. 134, p. 670-671.

White, P.S., 1979, Pattern, process, and natural disturbance in vegetation: Botanical Review, v. 45, p. 229-299.

Whittaker, R.H., and Levin, S.A., 1977, The role of mosiac phenomena in natural communities: Theoretical Population Biology, v. 12, p. 117-139.

Wilshire, H.G., and Reneau, S.L., 1992, Geomorphic surfaces and underlying deposits of the Mohave Mountains Piedmont, lower Colorado River, Arizona: Zeitschrift fur Geomorphologie N.F., v. 36, no. 2, p. 207-226. 


\section{APPENDIX 1}

Soil descriptions for geomorphic units underlying each target site. Soil pits were usually examined in various locations around each site to confirm the continuity of geomorphic unit; descriptions were recorded for the most representative soil of the site. Key to abbreviations is given at end of appendix. Parent material is discussed in text.

\section{SITE A-2}

Geomorphic surface: Q3b; Bar/swales, cut with active channels. Elevation: 463 m

\begin{tabular}{|c|c|c|c|c|c|c|c|}
\hline \multirow[b]{2}{*}{ Horizon } & \multicolumn{2}{|l|}{ Depth/ } & \multirow{2}{*}{$\begin{array}{c}\text { Color } \\
\text { Dry (Moist) }\end{array}$} & \multicolumn{2}{|c|}{ Consistency } & \multirow[b]{2}{*}{ Structure } & \multirow{2}{*}{$\begin{array}{c}\text { Reaction/ } \\
\mathrm{CaCO}_{3} \text { Stage }\end{array}$} \\
\hline & Boundary & Texture & & Dry & Wet & & \\
\hline $\mathrm{A}$ & $0-10, a$ & $\mathrm{~kg}, \mathrm{ls}$ & $\begin{array}{c}\text { 10YR5/4 } \\
(10 \mathrm{YR} 3 / 4)\end{array}$ & lo & so, po & wV & es \\
\hline $\mathrm{C} 1$ & $10-20, \mathrm{c}$ & $\mathrm{kg}, \mathrm{sl}$ & $\begin{array}{l}\text { 10YR6/4 } \\
\text { (10YR4/4) }\end{array}$ & so & ss, po & wsbk & ev; Stage I \\
\hline $\mathrm{C} 2$ & $20-82, \mathrm{c}$ & $\mathrm{kg}, \mathrm{ls}$ & $\begin{array}{l}\text { 10YR6/4 } \\
\text { (10YR4/4) }\end{array}$ & so & so, po & $\mathrm{sg}$ & ev; Stage I \\
\hline $\mathrm{C} 3$ & $82-117+$ & $\mathrm{gk}, \mathrm{s}$ & $\begin{array}{c}\text { 10YR6/4 } \\
\text { (10YR4/4) }\end{array}$ & so & so, po & $\mathrm{sg}$ & ev; Stage I \\
\hline
\end{tabular}

\section{SITE A-4}

Geomorphic Surface: Q3a over Q2; slight bar/swale on terrace 1-2 m above active channel. Elevation: $597 \mathrm{~m}$

\begin{tabular}{|c|c|c|c|c|c|c|c|}
\hline \multicolumn{3}{|c|}{ Depth/ } & \multirow{2}{*}{$\begin{array}{c}\text { Color } \\
\text { Dry (Moist) }\end{array}$} & \multicolumn{2}{|c|}{ Consistency } & \multirow[b]{2}{*}{ Structure } & \multirow{2}{*}{$\begin{array}{c}\text { Reaction/ } \\
\mathrm{CaCO}_{3} \text { Stage }\end{array}$} \\
\hline Horizon & Boundary & Texture & & Dry & Wet & & \\
\hline A & $0-10$, a & $\mathrm{kg}, \mathrm{sl}$ & $\begin{array}{c}\text { 10YR6/4 } \\
\text { (10YR4/4) }\end{array}$ & so & ss, po & wV & es \\
\hline $\mathrm{C} 1$ & $10-45, \mathrm{~g}$ & $\mathrm{~kg}, 1 \mathrm{~s}$ & $\begin{array}{c}\text { 10YR6/3 } \\
\text { (10YR4/3) }\end{array}$ & so & ss, po & $\mathrm{m}$ & ev; Stage I \\
\hline $\mathrm{C} 2$ & $45-70, \mathrm{a}, \mathrm{w}$ & $\mathrm{kg}, 1 \mathrm{~s}$ & $\begin{array}{c}\text { 10YR6/3 } \\
(10 \mathrm{YR} 4 / 3)\end{array}$ & so & so, po & $\mathrm{m}$ & es; Stage I \\
\hline II C3 & $60-130+$ & $\mathrm{kg}, \mathrm{ls}$ & $\begin{array}{c}\text { 8YR6/4 } \\
\text { (8YR4/4) }\end{array}$ & $\mathrm{sh}$ & ss, po & wsbk & ev; Stage I \\
\hline
\end{tabular}

Note: Uncomfortably overlies buried soil indicated by a well-developed argillic or petrocalcic horizon at depth of 20-60 cm.

\section{SITE B-1}

Geomorphic Surface: Q1; isolated ridgetop 5+m above active channel. Elevation: $518 \mathrm{~m}$

\begin{tabular}{|c|c|c|c|c|c|c|c|}
\hline \multicolumn{3}{|c|}{ Depth/ } & \multirow{2}{*}{$\begin{array}{c}\text { Color } \\
\text { Dry (Moist) }\end{array}$} & \multicolumn{2}{|c|}{ Consistency } & \multirow[b]{2}{*}{ Structure } & \multirow{2}{*}{$\begin{array}{c}\text { Reaction/ } \\
\mathrm{CaCO}_{3} \text { Stage }\end{array}$} \\
\hline Horizon & Boundary & Texture & & Dry & Wet & & \\
\hline A & $0-5, a$ & $\mathrm{~kg}, \mathrm{sl}$ & $\begin{array}{c}\text { 10YR6/3 } \\
(10 \mathrm{YR} 3 / 3)\end{array}$ & so & ss, po & wpl & $\mathrm{ev}$ \\
\hline $\mathrm{C} 1$ & $5-28, c$ & $\mathrm{~kg}, \mathrm{sl}$ & $\begin{array}{l}\text { 10YR7/3 } \\
(10 \mathrm{YR} 4 / 3)\end{array}$ & so & ss, po & wsbk & ev \\
\hline $\mathrm{C} 2$ & $28-50, \mathrm{c}$ & $\mathrm{kg}, \mathrm{sl}$ & $\begin{array}{c}\text { 10YR6/3 } \\
(10 \mathrm{YR} 3 / 3)\end{array}$ & so & so, po & wsbk & ev; Stage II \\
\hline $\mathrm{C} 3$ & $50-70+$ & $\mathrm{kg}, \mathrm{sl}$ & NA & $\mathrm{vh}$ & NA & $\mathrm{m}$ & ev; Stage III \\
\hline
\end{tabular}




\section{SITE B-2}

Geomorphic Surface: Q2a; well-varnished pavement on flat ridge 3+ $\mathrm{m}$ above active channel. Elevation: $646 \mathrm{~m}$

\begin{tabular}{|c|c|c|c|c|c|c|c|}
\hline \multicolumn{3}{|c|}{ Depth/ } & \multirow{2}{*}{$\begin{array}{c}\text { Color } \\
\text { Dry (Moist) }\end{array}$} & \multicolumn{2}{|c|}{ Consistency } & \multirow[b]{2}{*}{ Structure } & \multirow{2}{*}{$\begin{array}{c}\text { Reaction/ } \\
\mathrm{CaCO}_{3} \text { Stage }\end{array}$} \\
\hline Horizon & Boundary & Texture & & Dry & Wet & & \\
\hline A & $0-8, \mathrm{a}$ & $\mathrm{sl}$ & $\begin{array}{c}7.5 \mathrm{YR} 5 / 4 \\
(7.5 \mathrm{YR} 3 / 4)\end{array}$ & so & ps, ss & wpl & es \\
\hline B & $8-28, c$ & $\mathrm{~kg}, \mathrm{scl}$ & $\begin{array}{c}5 \mathrm{YR} 5 / 4 \\
(5 \mathrm{YR} 3 / 4)\end{array}$ & so & $\mathrm{s}, \mathrm{ps}$ & sbk & es; Stage II \\
\hline $\mathrm{BC}$ & $28-52, a$ & $\mathrm{~kg}, \mathrm{scl}$ & $\begin{array}{c}7.5 \mathrm{YR} 5 / 4 \\
(7.5 \mathrm{YR} 4 / 6)\end{array}$ & so & $\mathrm{s}, \mathrm{p}$ & sbk & ev; Stage II \\
\hline $\mathrm{C}$ & $52-60+$ & NA & $\begin{array}{l}\text { NA } \\
\text { (NA) }\end{array}$ & $\mathrm{vh}$ & NA & $\mathrm{m}$ & ev; Stage III \\
\hline
\end{tabular}

\section{SITE B-3}

Geomorphic Surface: Q1; ridgetop 4+ m above active channel. Elevation: 695 m

\begin{tabular}{|c|c|c|c|c|c|c|c|}
\hline \multicolumn{3}{|c|}{ Depth/ } & \multirow{2}{*}{$\begin{array}{c}\text { Color } \\
\text { Dry (Moist) }\end{array}$} & \multicolumn{2}{|c|}{ Consistency } & \multirow[b]{2}{*}{ Structure } & \multirow{2}{*}{$\begin{array}{c}\text { Reaction/ } \\
\mathrm{CaCO}_{3} \text { Stage }\end{array}$} \\
\hline Horizon & Boundary & Texture & & Dry & Wet & & \\
\hline A & $0-5, \mathrm{c}$ & gsl & $\begin{array}{c}\text { 10YR6/4 } \\
\text { (10YR4/4) }\end{array}$ & so & ss, po & $\mathrm{pl}, \mathrm{v}$ & ev \\
\hline $\mathrm{C} 1$ & $5-35, d$ & gsl & $\begin{array}{c}\text { 10YR6/4 } \\
\text { (10YR4/4) }\end{array}$ & so & ss, ps & sbk & ev; Stage I \\
\hline $\mathrm{C} 2$ & $35-60$ & gsl & $\begin{array}{c}\text { 10YR6/4 } \\
\text { (10YR4/4) }\end{array}$ & sh & ss, ps & sbk & $\begin{array}{l}\text { ev; eroded } \\
\text { Stage IV }\end{array}$ \\
\hline $\mathrm{C} 3$ & $60+$ & NA & $\begin{array}{l}\text { NA } \\
\text { (NA) }\end{array}$ & vh & NA & lam & ev; Stage IV \\
\hline
\end{tabular}

Note: Site has a highly variable, eroded petrocalcic horizon.

\section{SITE B-5}

Geomorphic Surface: Q1; terrace 10+ m above active channel. Elevation: 585 m

\begin{tabular}{ccccccccc}
\hline & Depth/ & \multicolumn{2}{c}{ Color } & \multicolumn{2}{c}{ Consistency } & \multicolumn{2}{c}{ Reaction/ } \\
Horizon & Boundary & Texture & Dry (Moist) & Dry & Wet & Structure & CaCO $_{3}$ Stage \\
\hline BC & $0-43$, a & gl & NA & sh & ps, sh? & sbk & ev \\
C & $43+$ & NA & NA & vh & NA & lam & ev; Stage IV \\
\hline
\end{tabular}

Note: Site represents an eroded soil with Stage IV petrocalcic horizon. Highly variable BC horizon contains blocks of eroded carbonate. 
SITE C-0

Geomorphic Surface: Intermittently active bajada 10-12 km from mountain front. Elevation: $475 \mathrm{~m}$

\begin{tabular}{|c|c|c|c|c|c|c|c|}
\hline \multicolumn{3}{|c|}{ Depth/ } & \multirow{2}{*}{$\begin{array}{c}\text { Color } \\
\text { Dry (Moist) }\end{array}$} & \multicolumn{2}{|c|}{ Consistency } & \multirow[b]{2}{*}{ Structure } & \multirow{2}{*}{$\begin{array}{l}\text { Reaction/ } \\
\mathrm{CaCO}_{3} \text { Stage }\end{array}$} \\
\hline Horizon & Boundary & Texture & & Dry & Wet & & \\
\hline $\mathrm{A}$ & $0-8, \mathrm{c}$ & $\mathrm{sl}$ & $\begin{array}{c}\text { 10YR6/4 } \\
\text { NA }\end{array}$ & lo & ss, po & pl, wv & es \\
\hline $\mathrm{C} 1$ & $8-29, \mathrm{c}$ & 1s & $\begin{array}{c}\text { 7.5YR6/4 } \\
\text { NA }\end{array}$ & so & ss, po & wsbk & ev; Stage I \\
\hline $\mathrm{C} 2$ & $29-61, \mathrm{~g}$ & ls & $\begin{array}{c}\text { 7.5YR6/4 } \\
\text { NA }\end{array}$ & $\mathrm{sh}$ & so, po & wsbk & ev; Stage I-II \\
\hline $\mathrm{C} 3$ & $61-125+$ & ls & $\begin{array}{c}\text { 7.5YR6/4 } \\
\text { (NA) }\end{array}$ & lo & so, po & $\mathrm{m}$ & es; variable \\
\hline
\end{tabular}

\section{SITE C-1}

Geomorphic Surface: Intermittently active bajada 10-12 km from mountain front. Elevation: $524 \mathrm{~m}$

\begin{tabular}{|c|c|c|c|c|c|c|c|}
\hline \multicolumn{3}{|c|}{ Depth/ } & \multirow{2}{*}{$\begin{array}{c}\text { Color } \\
\text { Dry (Moist) }\end{array}$} & \multicolumn{2}{|c|}{ Consistency } & \multirow[b]{2}{*}{ Structure } & \multirow{2}{*}{$\begin{array}{c}\text { Reaction/ } \\
\mathrm{CaCO}_{3} \text { Stage }\end{array}$} \\
\hline Horizon & Boundary & Texture & & Dry & Wet & & \\
\hline $\mathrm{A}$ & $0-11, \mathrm{c}$ & gsl & $\begin{array}{c}\text { 10YR5/4 } \\
(10 \mathrm{YR} 3 / 4)\end{array}$ & lo & ss, po & $\mathrm{pl}$ & eo \\
\hline $\mathrm{C} 1$ & 11-30, g & gls & $\begin{array}{c}\text { 7.5YR5/4 } \\
(7.5 Y R 4 / 4)\end{array}$ & so & ss, po & wsbk & eo \\
\hline $\mathrm{C} 2$ & $30-75, \mathrm{~g}$ & gls & $\begin{array}{c}\text { 7.5YR5/4 } \\
\text { (7.5YR4/4) }\end{array}$ & sh & ss, po & wsbk & es-ev; Stage I \\
\hline $\mathrm{C} 3$ & $75-110, \mathrm{c}$ & gls & $\begin{array}{c}\text { 7.5YR6/4 } \\
(7.5 \mathrm{YR} 5 / 4)\end{array}$ & sh & so, po & wsbk & ev; Stage II \\
\hline $\mathrm{C} 4$ & $110-130+$ & gls & $\begin{array}{l}7.5 \mathrm{YR} 5 / 4 \\
\text { (NA) }\end{array}$ & sh-h & so, po & sbk & $\begin{array}{l}\text { eo-ev; possible } \\
\text { gypsum horizon }\end{array}$ \\
\hline
\end{tabular}

\section{SITE K-1}

Geomorphic Surface: Intermittently active bajada $1 \mathrm{~km}$ from mountain front. Elevation: $1048 \mathrm{~m}$

\begin{tabular}{|c|c|c|c|c|c|c|c|}
\hline \multicolumn{3}{|c|}{ Depth/ } & \multirow{2}{*}{$\begin{array}{c}\text { Color } \\
\text { Dry (Moist) }\end{array}$} & \multicolumn{2}{|c|}{ Consistency } & \multirow[b]{2}{*}{ Structure } & \multirow{2}{*}{$\begin{array}{c}\text { Reaction/ } \\
\mathrm{CaCO}_{3} \text { Staqe }\end{array}$} \\
\hline Horizon & Boundary & Texture & & Dry & Wet & & \\
\hline A & $0-8, a$ & gls & $\begin{array}{c}\text { 7.5YR5/4 } \\
(7.5 Y R 3 / 4)\end{array}$ & lo & so, po & $\mathrm{m}$ & es \\
\hline $\mathrm{AB}$ & $8-30, \mathrm{~g}$ & gsl & $\begin{array}{c}\text { 7.5YR5/4 } \\
\text { (7.5YR4/4) }\end{array}$ & $\mathrm{sh}$ & so, ps & wsbk & ev; Stage I \\
\hline BA & $30-41, \mathrm{c}$ & gsl & $\begin{array}{c}\text { 7.5YR5/4 } \\
\text { (7.5YR4/4) }\end{array}$ & $\mathrm{sh}$ & ss, ps & wsbk & ev; Stage II \\
\hline B & $41-63, \mathrm{~g}$ & gsl-scl & $\begin{array}{c}\text { 5YR4/6 } \\
\text { (5YR3/4) }\end{array}$ & sh & ss, ps & sbk & ev; Stage II \\
\hline $\mathrm{C}$ & $63-130+$ & gsl & $\begin{array}{l}\text { 10YR7/4 } \\
\text { (10YR5/4) }\end{array}$ & $\mathrm{h}$ & ss, po & sbk & ev; Stage II \\
\hline
\end{tabular}


SITE K-2y

Geomorphic Surface: Active alluvial flood plain lined with terraces. Elevation: 1058

\begin{tabular}{|c|c|c|c|c|c|c|c|}
\hline \multicolumn{3}{|c|}{ Depth/ } & \multirow{2}{*}{$\begin{array}{c}\text { Color } \\
\text { Dry (Moist) }\end{array}$} & \multicolumn{2}{|c|}{ Consistency } & \multirow[b]{2}{*}{ Structure } & \multirow{2}{*}{$\begin{array}{c}\text { Reaction/ } \\
\mathrm{CaCO}_{3} \text { Stage }\end{array}$} \\
\hline Horizon & Boundary & Texture & & Dry & Wet & & \\
\hline $\mathrm{A}$ & $0-8, \mathrm{c}$ & gls & $\begin{array}{l}\text { 10YR5/4 } \\
\text { (10YR4/4) }\end{array}$ & lo & so, po & $\mathrm{m}$ & eo \\
\hline $\mathrm{C} 1$ & $8-62, \mathrm{~g}$ & gls & $\begin{array}{c}\text { 10YR5/4 } \\
(10 \mathrm{YR} 4 / 4)\end{array}$ & so & so, po & $\mathrm{sg}$ & eo \\
\hline $\mathrm{C} 2$ & $62-143+$ & gls & $\begin{array}{c}\text { 10YR5/4 } \\
\text { (NA) }\end{array}$ & so & so, po & wsbk & e; Weak Stage I \\
\hline
\end{tabular}

\section{SITE K-20}

Geomorphic Surface: Isolated alluvial flood plain. Elevation: 1061

\begin{tabular}{|c|c|c|c|c|c|c|c|}
\hline \multicolumn{3}{|c|}{ Depth/ } & \multirow{2}{*}{$\begin{array}{c}\text { Color } \\
\text { Dry (Moist) }\end{array}$} & \multicolumn{2}{|c|}{ Consistency } & \multirow[b]{2}{*}{ Structure } & \multirow{2}{*}{$\begin{array}{c}\text { Reaction/ } \\
\mathrm{CaCO}_{3} \text { Staqe }\end{array}$} \\
\hline Horizon & Boundary & Texture & & Dry & Wet & & \\
\hline A & $0-10$, a & sl & $\begin{array}{c}\text { NA } \\
(10 \mathrm{YR} 3 / 4)\end{array}$ & so & po, ss & sbk & $\mathrm{e}$ \\
\hline BA & $10-20, \mathrm{c}$ & $\mathrm{scl}$ & $\underset{\text { (5YR3/4) }}{\text { NA }}$ & sh & $\mathrm{s}, \mathrm{p}$ & sbk & eo \\
\hline B & $20-60, \mathrm{~g}$ & gscl & $\begin{array}{c}2.5 \mathrm{YR} 3 / 4 \\
(2.5 \mathrm{YR} 4 / 4)\end{array}$ & $\mathrm{vh}$ & $\mathrm{s}, \mathrm{p}$ & $\mathrm{pr}$ & eo \\
\hline $\mathrm{BC}$ & $60-82, \mathrm{~g}$ & sl & $\underset{(2.5 \mathrm{YR} 3 / 4)}{\mathrm{NA}}$ & $\mathrm{h}$ & ss, po & sbk & eo-ev; Stage I \\
\hline $\mathrm{C} 1$ & $82-100, c$ & ls & $\begin{array}{c}\mathrm{NA} \\
(2.5 \mathrm{YR} 3 / 4)\end{array}$ & sh & so, po & wsbk & eo-ev; Stage I \\
\hline $\mathrm{C} 2$ & $100-130$ & gls & $\underset{\text { (5YR5/4) }}{\text { NA }}$ & so & so, po & sg & es-ev; Stage I \\
\hline $\mathrm{C} 3$ & $130-160+$ & ls & $\begin{array}{c}\mathrm{NA} \\
(7.5 \mathrm{YR} 4 / 4)\end{array}$ & lo & sl, po & $\mathrm{m}$ & eo \\
\hline
\end{tabular}


KEY TO APPENDIX I

\begin{tabular}{lll}
\hline & BOUNDARY & \multicolumn{1}{c}{ TEXTURE } \\
\hline a-abrupt & s-sand & gsl-gravelly sandy loam \\
c-clear & ls-loamy sand & gls-gravelly loamy sand \\
g-gradual & sl-sandy loam & gl-gravelly loam \\
d-diffuse & l-loam & g-gravel \\
w-wavy & scl-sandy clay loam & sg-sandy gravel \\
& gscl-gravelly sandy clay loam & kg-cobbly gravel \\
\hline
\end{tabular}

\section{CONSISTENCY}

\begin{tabular}{lll}
\hline \multicolumn{1}{c}{ DRY } & WET & \\
\hline lo-loose & so-non-sticky & po-non-plastic \\
so-soft & ss-slightly sticky & ps-slightly plastic \\
sh-slightly hard & s-sticky & p-plastic \\
h-hard & & \\
vh-very hard & & \\
\hline
\end{tabular}

\begin{tabular}{ll}
\hline \multicolumn{1}{c}{ STRUCTURE } & REACTION \\
\hline m-massive & eo-no effervescence \\
sg-single grained & e-slightly effervescent \\
wv-weakly vesicular & es-strongly effervescent \\
gr-granular & ev-violently effervescent \\
pl-platy & \\
wpl-weakly platy & \\
pr-prismatic & \\
sbk-subangular blocky & \\
wsbk-weakly subangular blocky & \\
lam-laminar & \\
\hline
\end{tabular}

For detailed information on the nomenclature used see Soil Survey Staff (1975). 


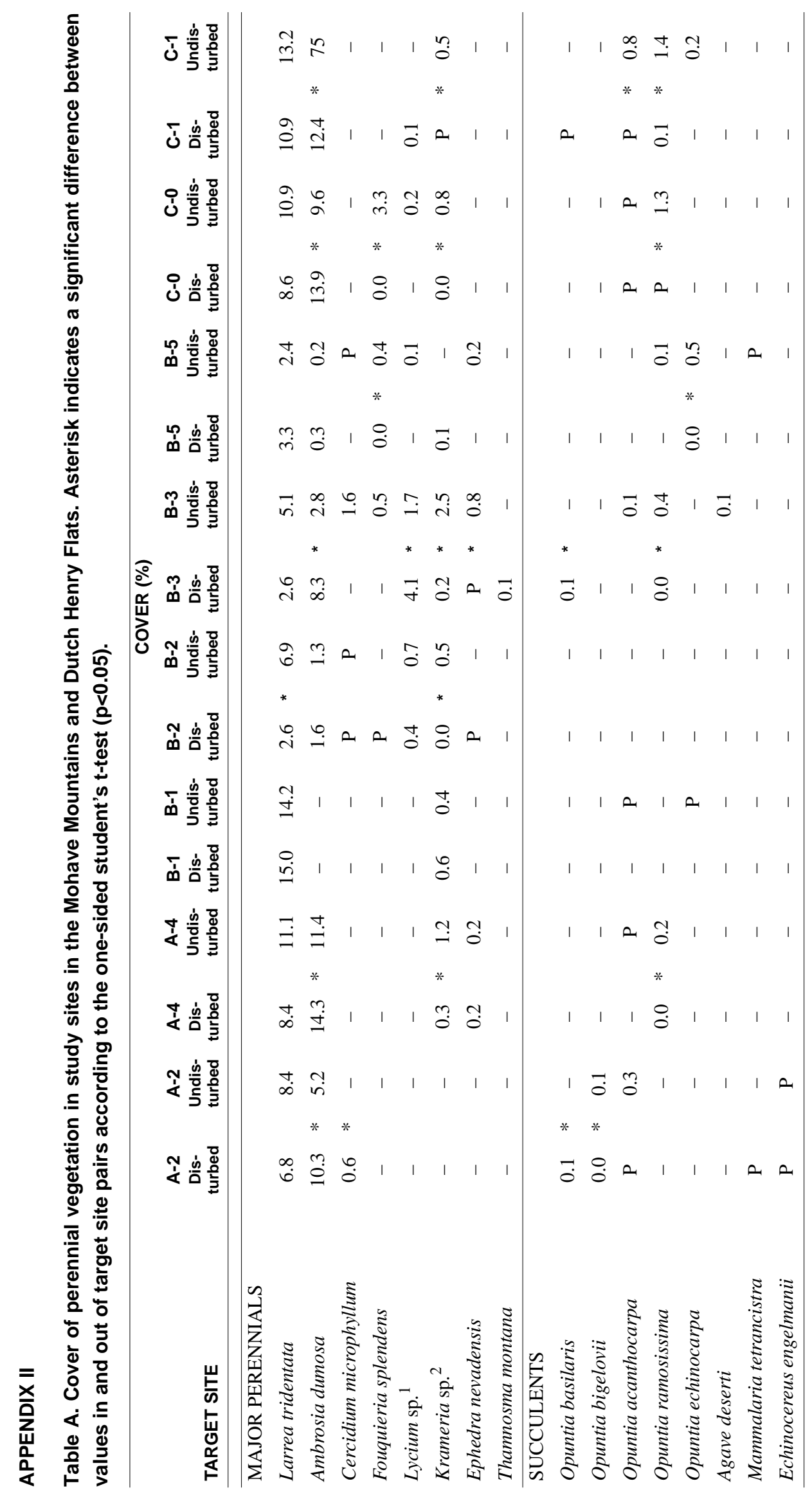




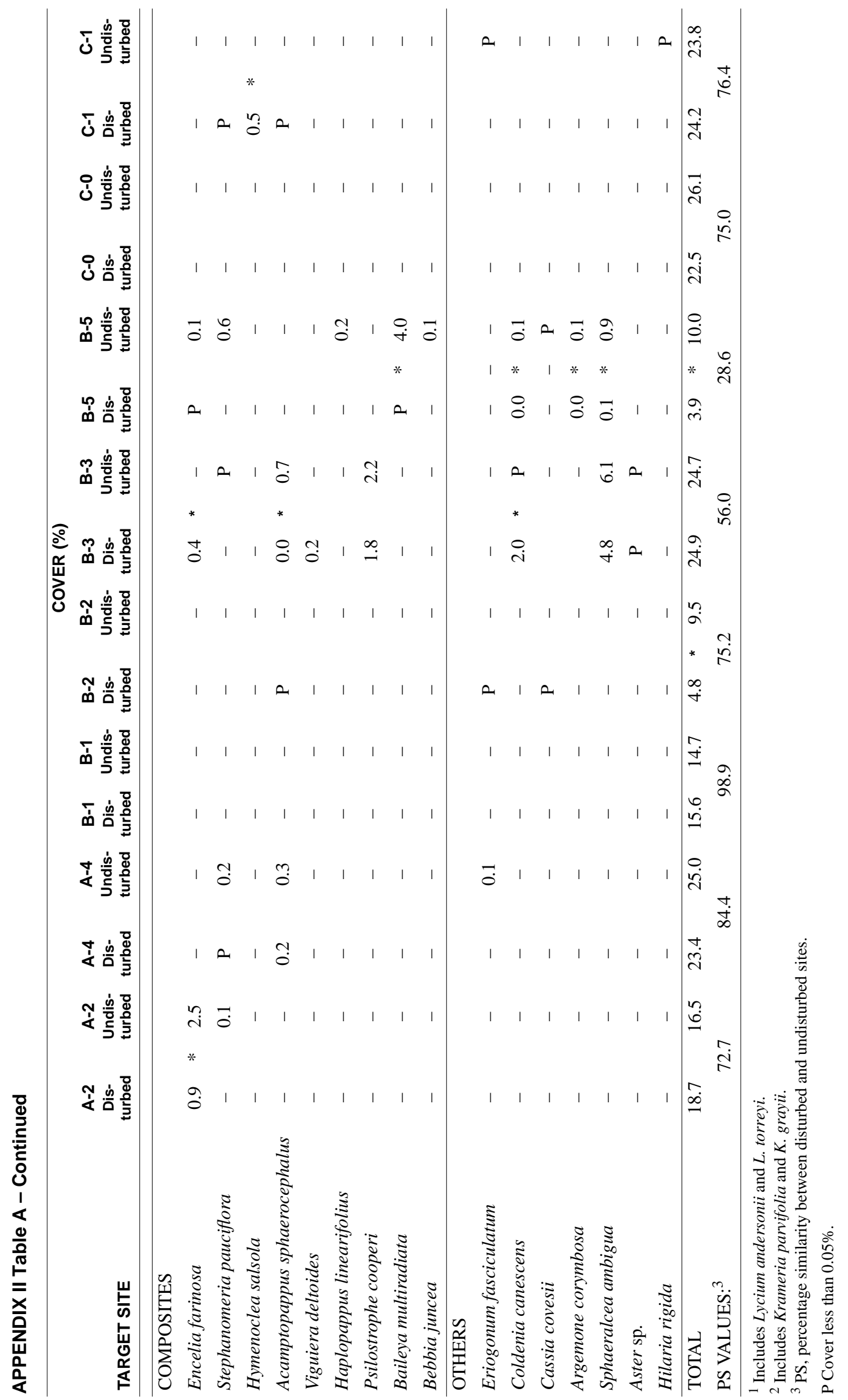




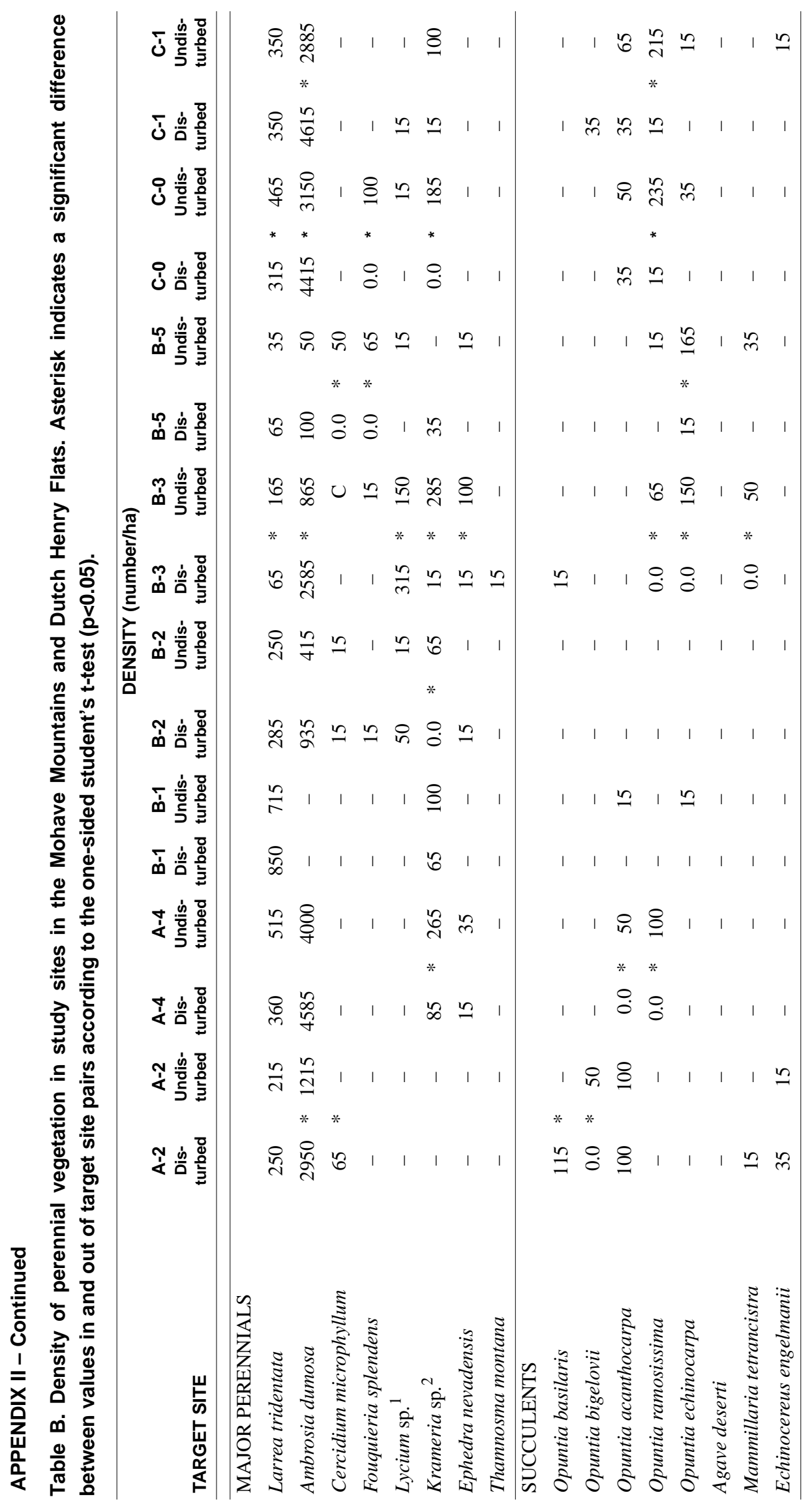




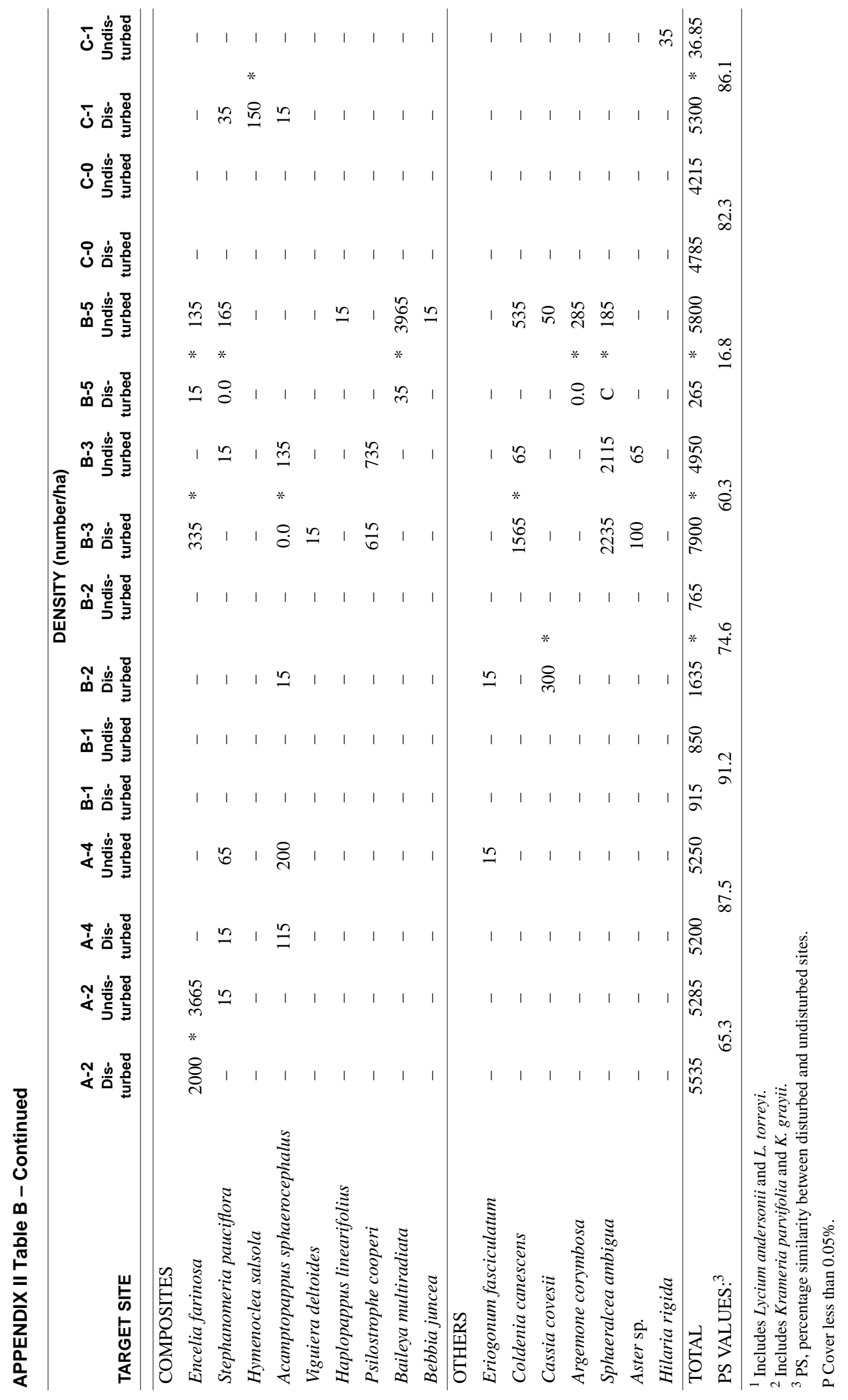




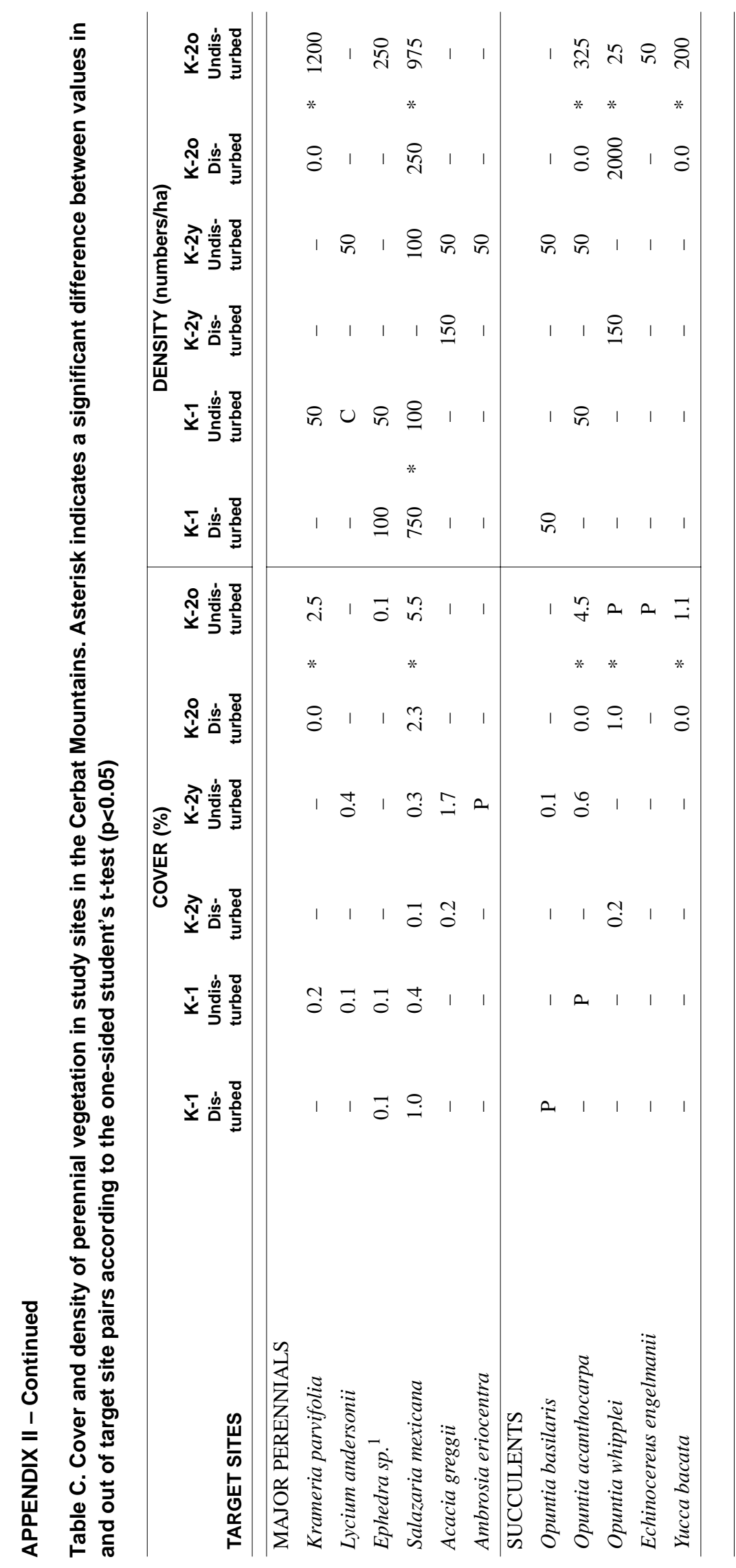




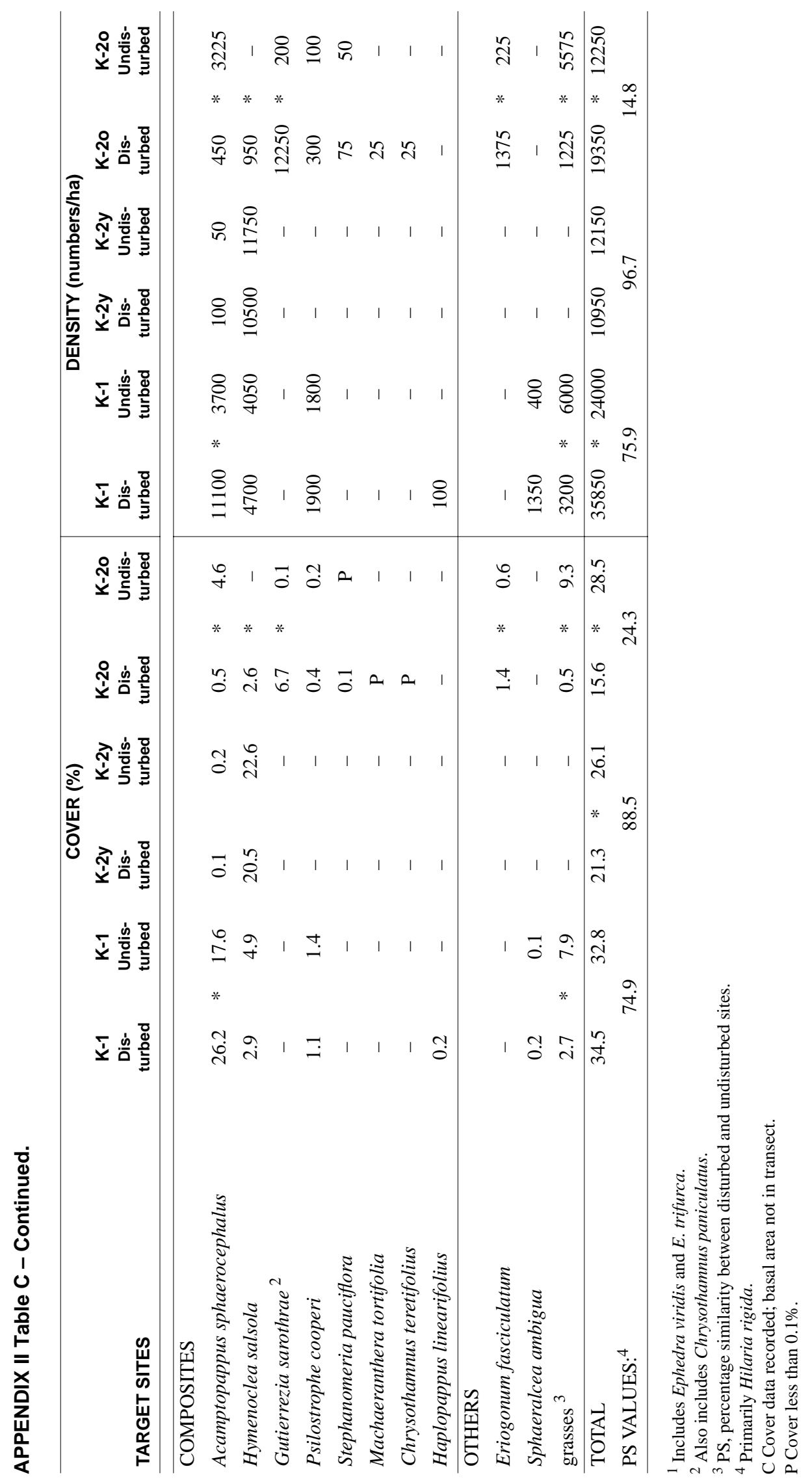

